\title{
KURGANS AND THEIR BUILDERS \\ The Great Hungarian Plain at the dawn of the Bronze Age ${ }^{1}$
}

\section{JÁNOS DANI ${ }^{2}$}

Hungarian Archaeology Vol. 9 (2020), Summer, pp. 1-20. doi: https://doi.org/10.36338/ha.2020.2.5

Dedicated to Prof. Dr. Pál Sümegi DSc, University Professor,

Director of the Department of Geology and Palaeontology on the occasion of his sixtieth birthday

Despite the fact that the enigmatic Yamnaya culture whose communities raised kurgans over their dead (known also as the people of the Pit-grave kurgans) has provided the lowest number of finds in the archaeology of the Carpathian Basin to date, it is nevertheless regarded as one of the most important archaeological cultures which profoundly shaped the history of Europe after 3000 BC in the light of the new advances in, and fresh findings of archaeogenetic and isotope studies during the past decade. The core distribution of the Yamnaya culture was the vast grass steppe extending from Kazakhstan to the northern and western Pontic, while the westernmost mass presence of these prehistoric pastoralist communities can be found on the Great Hungarian Plain.

\section{INTRODUCTION}

Although their number has dwindled during the bygone centuries and millennia, the enormous earthen mounds raised over prehistoric burials remain distinctive elements of the landscape of the Great Hungarian Plain. Often mistakenly called kunhalom ["Cumanian mound"] in common Hungarian parlance, ${ }^{3}$ the artificial mounds erected over burials predominantly dating from the close of the Copper Age and the Early Bronze Age (late fourth-earlier third millennium BC), which in archaeological scholarship are designated as kurgans, a word of Turkic-Mongolian ancestry, have fascinated scholars engaged in archaeological and historical studies since the nineteenth century. A heated scholarly debate emerged in the mid-nineteenth century on whether these mounds were natural formations or man-made, artificial relics (burial mounds or possibly look-out mounds). Following a study trip to Counties Békés and Csanád, József Szabó, professor of geology, argued in his academic inaugural lecture held in 1858 that the mounds were natural geological formations deposited by rivers (SzABÓ, 1859, 186-187). However, the question of how the mounds were formed was not laid to rest, particularly in historical and archaeological studies. Flóris Rómer played an outstanding role in this field, too, and he can be credited with inspiring further studies after he described the mounds he had seen on the outskirts of several settlements in his Bihar travelogue. He also mapped the mounds in several instances (Sz. MÁTHÉ, 1975, 309, map).

In the following, I shall offer a brief overview of the current state of research on these prehistoric mounds, whose study was begun over one and a half centuries ago (see Fig. 14 for the sites mentioned in the text).

\footnotetext{
1 The present study focuses on the kurgans erected during the Copper Age and the Early Bronze Age, and does not cover the burial mounds of the Iron Age and later periods.

Déri Múzeum, Debrecen; dani.janos@,derimuzeum.hu

3 A designation based on the erroneous historical arguments of the linguist and historian István Horvát (1784-1846). The prehistoric kurgans discussed here quite obviously have no connections whatsoever with the Cumanians (TóTH 2009, 481482; BaLÁzs-Kustár 2015, 16-18).
} 
János Dani $\bullet$ Kurgans and their Builders. The Great Hungarian Plain at the dawn of the Bronze Age

\section{KURGANS AND THEIR EXPLORERS ${ }^{4}$}

Motivated by thirst for discovery, curiosity and, obviously, the desire to unearth dazzling treasures, the spadework involved in, and experiences gained during, the very first excavations of these mounds offered some answers regarding their origins. Mention must be made of Pál Frenyó's rescue excavation at Dévaványa-Templomdomb in 1887, where in addition to the primary burial containing ochre that had been dug into the yellow subsoil and covered with wooden beams, two additional, secondary prehistoric burials deposited according to the same mortuary rite were uncovered under the disturbed kurgan, the location of a planned church building (FRENYó 1889). The very first kurgan excavations include the investigation of one of the mounds of the Kettőshalom ["Double mound"] on J. Hering's farmstead at Tiszaigar by Endre Tariczky, parish priest of Tiszafüred, and Béla Milesz in December 1898 (MILESZ, 1899, 81-83; TARICZKY, 1906). Tivadar Lehoczky's investigations of the kurgans at Král'ovský Chlmec (Királyhelmec)-Erős erdő in 1894 involved the excavation of a few small mounds of a kurgan group of the Early Bronze Age Corded Ware culture (LEHOCZKY, 1894a; 1894b).

The same period saw the investigation of the first mounds in Transylvania at Carpenii de Sus (Gyertyános) and Izvoarele (Bedellő) by Samu Fenichel in 1887-1888 (Fenichel, 1891a; 1891b), and at Ocland (Oklánd) by Endre Solymossy, who excavated no less than eighteen mounds within a span of two years, in 1894 and 1895 (Solymossy, 1895). Dr. András Jósa mentions several landowners who began the exploration of the kurgans on their estates on their own initiative or with the assistance of Jósa: Menyhért Okolicsányi of the Nyírkarász-Garahalom kurgan (1895); Baron József Vécsey of Geszteréd-Mound A (1868) and Count Jenő Pongrácz of the Potyhalom and Bashalom mounds at Tiszafüred (1889) (Jósa, 1897).

Following the initial adventuresome attempts, the first truly pioneering work with academic goals was undertaken by András Jósa in County Szabolcs-Szatmár-Bereg (JósA, 1897, JósA, 1915) and by Lajos Zoltai in County Hajdú-Bihar, who systematically surveyed and investigated countless prehistoric kurgans in the early decades of the twentieth century, principally in the Hortobágy region and along the Tócó Stream (Figs 1-2). Both polyhistors - who founded a regional museum in their respective county - soon realised

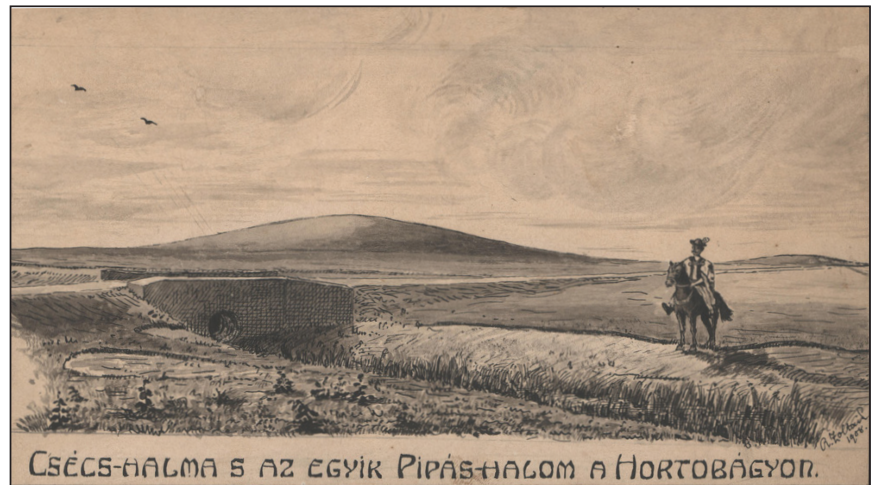

Fig. 1. Kurgans along the River Árkus in the Hortobágy region (watercolour: L. Zoltai)

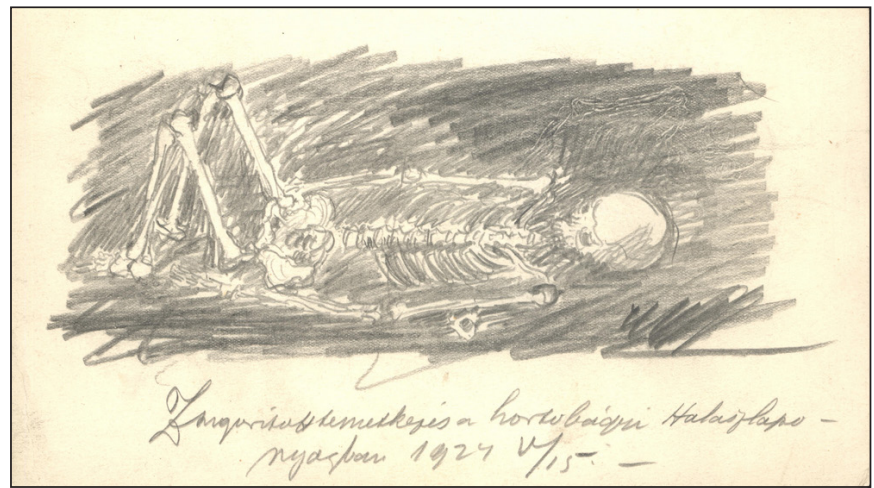

Fig. 2. The primary burial of the Hortobágy-Halászlaponyag kurgan with a neck vertebra by the left elbow (pencil drawing: L. Zoltai, 1924)

that the kurgans they had excavated had often been used during several periods, and not solely in prehistoric times. Zoltai cited the burials reflecting the disposal of the dead according to similar mortuary rites that had been unearthed under kurgans in southern Russia when interpreting the prehistoric tumulus burials he had excavated (ZoLTAI, 1911). He can be credited with the first systematic micro-regional kurgan research, in the course of which he surveyed and mapped the artificial mounds and elevations in the broader Debrecen

\footnotetext{
4 Secondary literature on this topic is extensive and covers a wide range of questions. This paper aims to provide a general overview, which is impossible within the framework of a short paper. Therefore, a bibliography more lengthy than what is usual for our journal is attached to the paper. - The editors
} 
János Dani $•$ Kurgans and their Builders. The Great Hungarian Plain at the dawn of the Bronze Age

area (ZolTAI, 1938). In the Voivodina, Bódog Milleker undertook pioneering work with the excavation of three mounds on the northern outskirts of Ulma (Homokszil) near Versec. Among these, he discovered an extraordinarily richly furnished burial in the centre of the kurgan located in the maize field of Ittebeácz: the west to east oriented crouched burial of a woman (or perhaps a child) with a lavish array of gold jewellery laid to rest in a wooden chamber (MILLEKER, 1901; DANI, 2020).

The systematic research of the prehistoric kurgans on the southern Hungarian Plain with a clear academic research agenda was undertaken by Gyula Gazdapusztai until his death in 1968. His main area of activity was County Békés, where, among others, the well-known kurgan cemetery of Kétegyháza is located (cf. BEDE et al., 2019, Fig. 1, 361-362, with the relevant literature). Nándor Kalicz has covered in detail the early excavations in his monograph on the Early Bronze Age (KALICZ, 1968). In 1979, István Ecsedy published his seminal monograph, The People of the Pit-Grave kurgans, in which he devoted a long section to the Hungarian research history of this period (ECSEDY, 1979).

\section{THE FIRST EASTERN EUROPEAN IMPACTS}

The publication of the Copper Age cemetery at Decea Mureşului (Marosdécse) (KovÁcs, 1932; 1944) and of the burial of the strong, sturdy man provisioned with a long obsidian blade from the site Csongrád-Kettöshalom (Bárdos-tanya), who was interred in an uncustomary position with his legs bent at the knees and drawn up (ECSEDY, 1973; 1979, 11-13; MARCSIK, 1974), provided conclusive evidence that Eastern European impacts can first be attested in the eastern half of the Carpathian Basin as early as the Tiszapolgár period, i.e. around 4400-4300 BC, which corresponds to the period of the Zepterträger (sceptre-bearers), the steppean cultural complex incorporating the Sredny Stog, Skeliya and Suvorovo-Novodanilovka cultures, in which the use of zoomorphic sceptres carved from stone can be noted among the male members of the Eastern European elite (Govedarica \& Kaiser, 1996; Manzura, 2000, 252-257; Govedarica, 2004, Anthony, 2007, Dergachev, 2007, 69-212; Nikolaeva, 2012). In addition to the stylised zoomorphic sceptres, certain outstanding male burials were furnished with globular and four-knobbed mace-heads of stone in the eastern half of the Carpathian Basin (GogÂLtan, 2011; Schuster et al., 2015).

The possibly earliest finds that can be associated with a kurgan burial come from the Nádas-halom kurgan located on the boundary between Békésszentandrás and Szarvas that was disturbed during road construction (MRT 8, Site 1/51, 85-86, P1. 19. 8a-c): a vessel decorated with the Wickelschnur technique, a variant of cord-impressed decoration (Fig. 3), dated to the Bodrogkeresztúr-Cernavodă I-Cucuteni CSălcuţa III-Šuplevec-Crnobuki-Bakarno Gumno period on typological grounds, i.e. to the onset of the fourth millennium BC (Roman et al., 1992, 35, 38-47, Abb. 2).

Thus, on the testimony of the archaeological record, we cannot assume any large-scale migrations into the Carpathian Basin from Eastern Europe - what we see is the infiltration of a few individuals or smaller groups at the most (HEYD, 2016, 60).

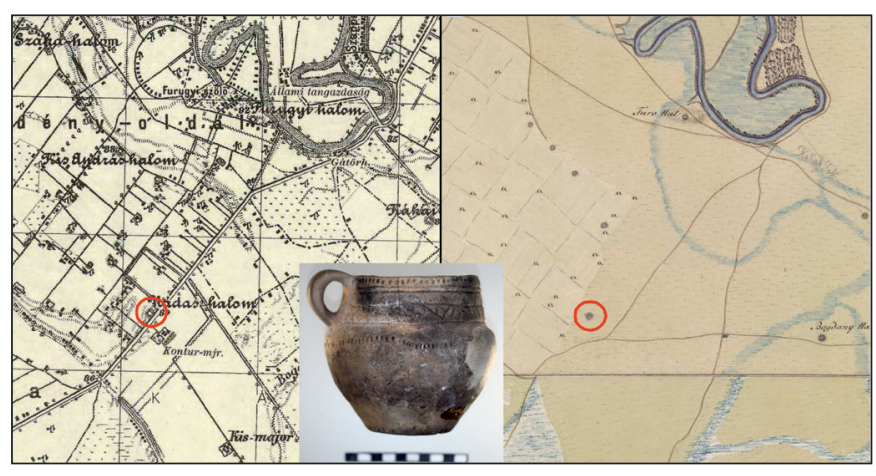

Fig. 3. The Békésszentandrás, Nádas-halom kurgan: detail of the maps of the Fourth and First Military Ordnance Survey and the vessel from the kurgan (photo: J. Szarka)

\section{THE PRE-YAMNAYA PERIOD AND THE FIRST KURGANS}

It is clear from the above that similarly to the northern and western Pontic and the Lower Danube region, the construction of the earliest kurgans in the Carpathian Basin cannot be linked to the Yamnaya culture. Some of the burials lying underneath enormous earthen mounds such as the grave of an extraordinarily tall man laid to rest in a hollowed-out tree trunk coffin underneath the Tiszavasvári-Deákhalom mound (Grave 6) and the interment of a man under the Tiszaigar-Kettőshalom mound, who was in all likelihood laid to 
János Dani $•$ Kurgans and their Builders. The Great Hungarian Plain at the dawn of the Bronze Age

rest according to a similar rite if the surviving description is to be believed, can be best likened to the mortuary rites of the Late Eneolithic Kvityana culture of the pre-Yamnaya period in the Dnieper region (DANI, 2011, 27-28; RASSAMAKIN, 2013, Figs 3-4, 116-117; HEYD, 2016, 60-62). The left-crouched primary burial underneath the Sárrétudvari-Örhalom kurgan (Grave 12) and the destroyed burial (actually a double burial with a child) of the Püspökladány-Kincsesdomb kurgan (Grave 3) can be likewise interpreted as pre-Yamnaya kurgan burials, which in part conform to the mortuary rites of the local Late Copper Age Baden culture and in part to those of the late Eneolithic Lower Mikhailovka culture distributed between the lower reaches of the Dniester and the Dnieper.

The first kurgans, rather small affairs during this period, were thus raised in the earlier fourth millennium, the period corresponding to the Middle Eneolithic in the Pontic (Rassamakin, 2012).

\section{THE PROCESS OF KURGANISATION}

Kurgans appeared en masse on the Great Hungarian Plain between 3100/3000 and 2600/2500 BC (Fig. 4). István Ecsedy had already noted the interaction between the local Late Copper Age Baden and Coţofeni communities and the newly arriving Yamnaya groups (ECSEDY, 1973, 19, 39; 1979, 51). Interaction between the local Late Copper Age population and the Eastern European immigrants can be documented on several levels.

(1) In Hungary, mounds were raised over biritual graves at Mezőcsát-Hörcsögös and Tiszavasvári-Gyepáros (KALICZ, 1999), while at the Skorenovac site in Serbia, the mounds were constructed

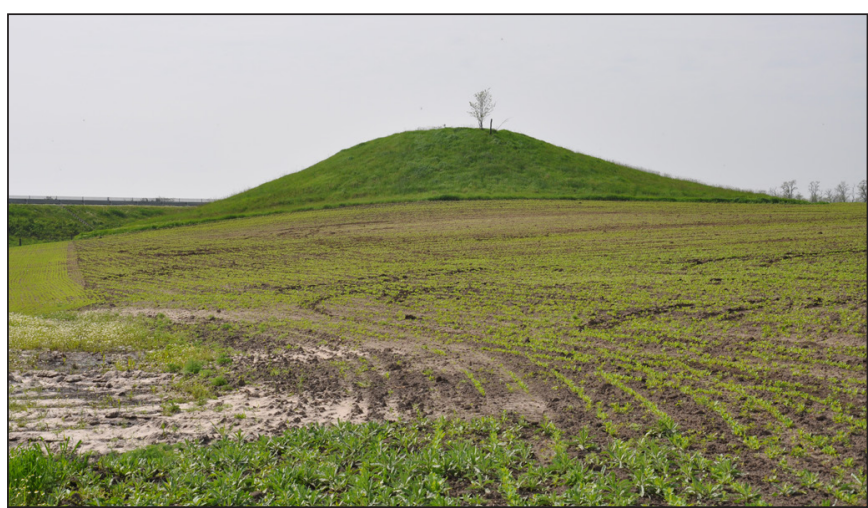

Fig. 4. The monumental kurgan of Hajdúnánás, Fekete-halom (photo: J. Dani) over thirteen inhumation burials of the Baden period (GARAŠANIN, 1959, 39, note 204). At two other Serbian sites, Perlez (Perlasz)-Batka C, Pašića Humka (Medovi,ć 1987, 79; Tasić, 1995, 153) and Padej (Padé)-Barnahát (GIRIĆ 1982, 102; 1987, 72, 76), as well as at the more recently investigated Hajdúnánás-Zagolya site (DANI et al., 2017, 142, Fig. 9), the kurgans were erected over settlements of the Baden culture. The minutely documented vertical stratigraphy of the Jabuka (Torontálalmás)-Tri Humke mound by Pančevo (Pancsova) indicated that the Baden-period layer was overlain by a settlement of the Kostolac culture and that the Pitgrave kurgan was constructed over the Eneolithic humus layer marking the end of the settlement's occupation (BuKvić, 1979, 14-18; 1987, 85; TAsić, 1995, 161). In many cases, pottery fragments of the Baden and Coţofeni cultures were found in the earth of the kurgans: Baden sherds at Debrecen-Ohat-Dunahalom and Dusnok-Garáb-halom, while Coţofeni pottery at Hajdúnánás-Tedej, Lyukas-halom, in the fill of Grave 11 at Sárrétudvari-Örhalom, at the Bare I mound near Kragujevac in Serbia (SREJović, 1976, 122, s1. 3-5) and at the Bodo-Movila lui Cordoş mound in the Banat in Romania (GogÂltan, 2013, 37, 40).

The minute re-assessment of the original reports of the Tiszaeszlár-Potyhalom mound enabled the reconstruction of a Baden-Yamnaya sequence. The mound was partially excavated by András Jósa and Count Jenö Pongrácz in 1889: they uncovered a burial in the mound's centre which to them was most unusual, being the west to east oriented interment of a "man of tall stature" crouched on the right side, deposited in a $71 \mathrm{~cm} \times 170 \mathrm{~cm} \times 30 \mathrm{~cm}$ large wooden chamber (JósA, 1897, 321). This excavation represents a milestone in archaeological research, too, for the first ribbed Leukas-type lock-ring, probably made of silver, was first reported from this burial. It was later stolen under mysterious circumstances (JósA, 1915, 199, Fig. 30; Fig. 5). In 1913, when the mound was levelled during road construction, a Baden-style amphora was recovered from the mound's earth, which was donated by Jenö Liptay to the Nyíregyháza museum (Fig. 6.1, Fig. 7.1). According to Dr. Jósa's hand-written notes, the vessel contained burnt animal bones (and possibly human bones, too, "which were mislaid and lost after their discovery"). The single surviving animal bone 
János Dani $\bullet$ Kurgans and their Builders. The Great Hungarian Plain at the dawn of the Bronze Age

is a sheep metatarsal burnt to a greyish colour (Fig. $6.2),{ }^{5}$ suggesting that the burial discovered during the construction work was a cremation of the Baden culture predating the kurgan's primary burial. This interpretation is underpinned by the field observations made by Jósa, according to whom "portions of the skeletons of two children mixed with ash and charcoal in two small heaps" lay beside each other near the kurgan's primary burial: "each heap was about a handful large. There were $4 \mathrm{~mm}$ long and wide burnt beads made of bone or shell (Tridacna gigas) among the bones" (JósA, 1915, 199). However, the description of the third inurned cremation burial ("at a height of $60 \mathrm{~cm}$, but in the upper, more compact black earth": JósA, 1915, 199; Fig. 7.2) clearly indicates that the kurgan was raised over a cremation cemetery of the Baden culture and that the Yamnaya burial was dug into the burial ground.

(2) The cremation burials of the Coţofeni culture came to light from some kurgans, for example from the Trnava 2 tumulus (Glavcovska mogila) (JovANoVIĆ, 1992).

(3) The primary grave of the Sprski Krstur (Szerbkeresztúr)-Slatinska humka kurgan was a cremation burial deposited in a Corded Ware amphora, a curious blend of Eastern European (Corded Ware vessel) and local Late Copper Age mortuary practices (GARAŠANIN, 1959, 51-52, Taf. 6,1; GIRIĆ, 1987, 74; Bulatović, 2014, 105-121, Fig. 2:20).

(4) Cremation burials of the Baden communities ringed with stones over which a small mound was raised are principally known from the Sajó Valley in southern Slovakia, for example from Gemer (Sajógömör) and Včelince (Méhi) (B. KovÁcs,

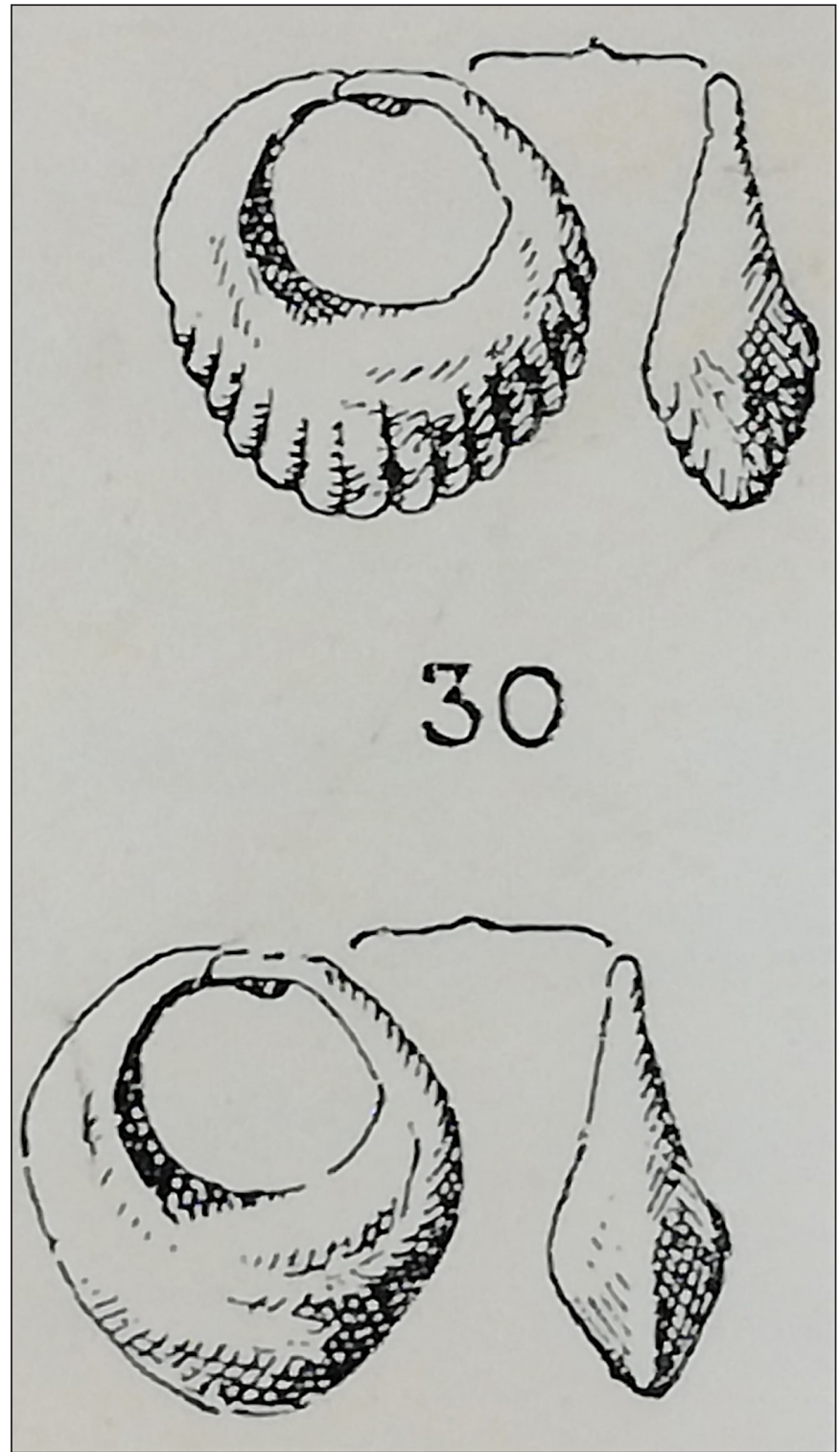

Fig. 5. The ribbed silver lock-ring from the TiszaeszlárPotyhalom kurgan and the plain silver lock-ring from the Buj-Feketehalom kurgan (drawing: A. Jósa) 1987; SACHSSE, 2012).

In the light of the above, there were various dimensions to the contacts between the local Late Copper Age populations and the pastoral Yamnaya communities.

The low mounds erected over some burials of the Baden culture can perhaps be seen as the adoption of Eastern European impacts reaching the Great Hungarian Plain at the close of the fourth millennium BC and as a reflection of new mortuary practices appearing among some neighbouring Late Copper Age communities. In these cases, we can probably conceptualise a peaceful process of acculturation.

The Late Copper Age sites over which large kurgans had been raised - and the finds from these sites in the earth of the kurgans - represent the symbolic inscription of the human landscapes created earlier. Viewed from this perspective, the appearance of many hundreds of kurgans across the greater part of the Great Hungarian Plain previously inhabited and used by Baden communities, which were subsequently occupied by pastoral Yamnaya groups, expressed the new political legitimation and imposed new traditions and new ritual practices as well as a new elite. We can but agree with Tünde Horváth that this process does 
János Dani • Kurgans and their Builders. The Great Hungarian Plain at the dawn of the Bronze Age

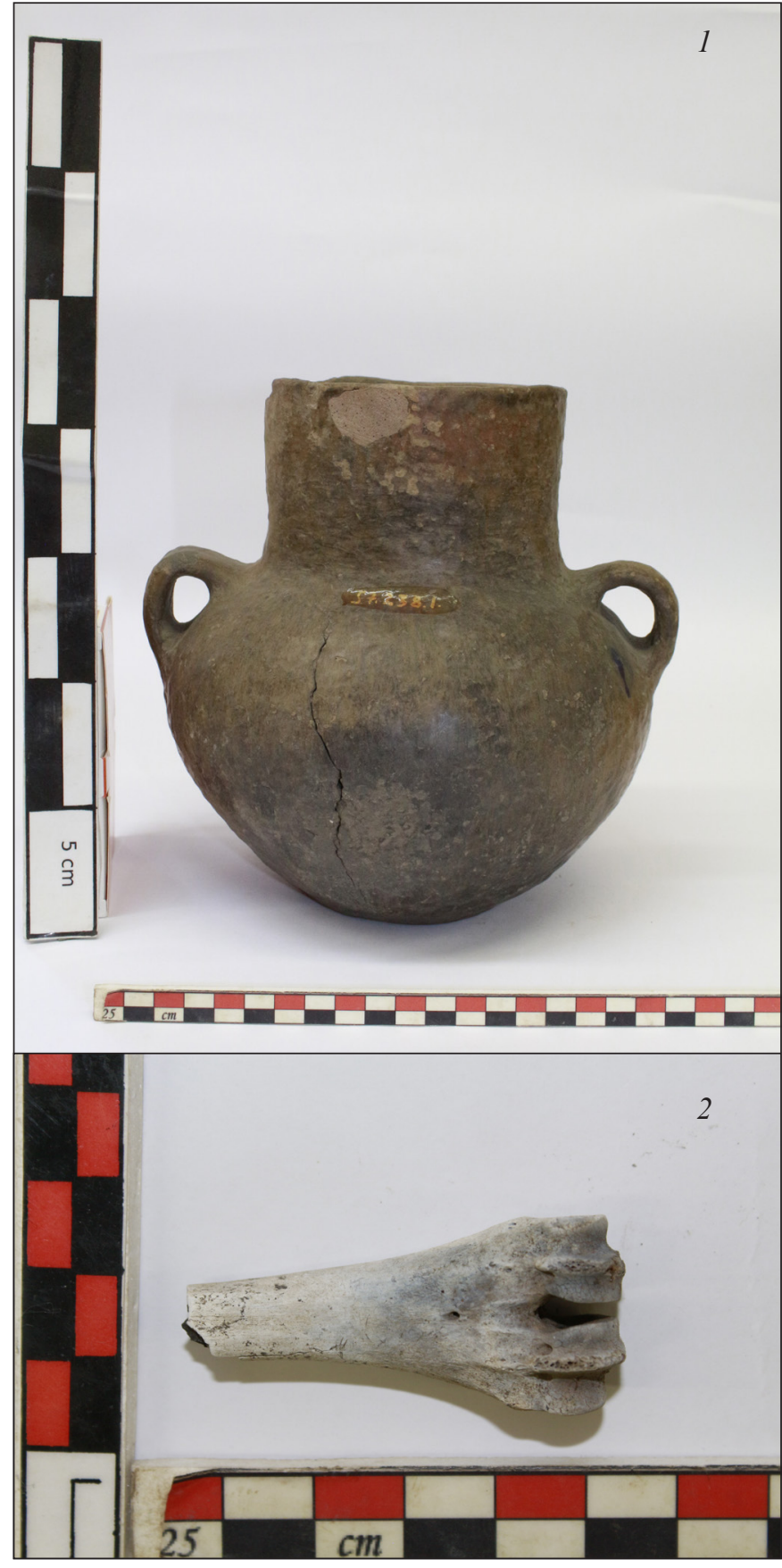

Fig. 6. Tiszaeszlár-Potyhalom: the Baden vessel (1) and the burnt sheep metatarsal inside it (2) (photo: A. Linzenbold)

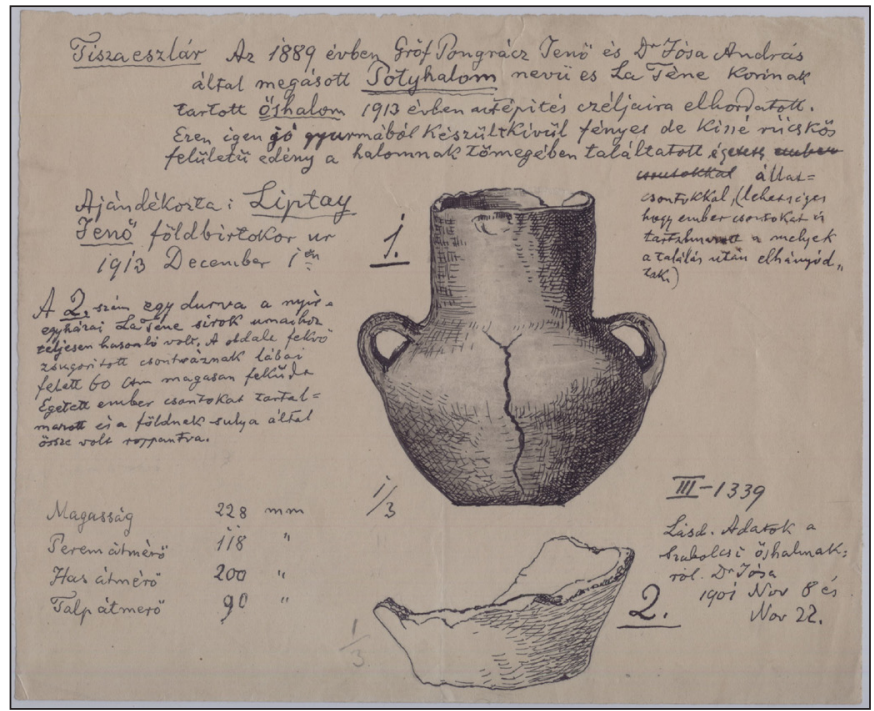

Fig. 7. Tiszaeszlár-Potyhalom: documentation of the cremation burial of the Baden culture found in the prehistoric humus layer dug by the kurgan's primary burial on the museum index card (drawing: A. Jósa)

not appear to have been particularly peaceful (HoRVÁTH, 2006, 112-116).

No matter how attractive or straightforward it might seem, the significant demographic decline during the Copper Age-Bronze Age transition in the eastern half of the Carpathian Basin cannot be simply explained by aggression and armed conflicts, given the conditions of the Copper Age (BARRAs, 2019). In other words, it seems most unlikely that the well-organised Baden population of the Great Hungarian Plain, living in larger communities, would have been completely wiped out or driven away by the pastoral groups arriving from Eastern Europe.

We can hardly leave out of consideration the new findings of pathogenic research, meaning that one hitherto unconsidered "variable" explaining the drastic population decline is that the population was decimated by epidemics caused by infectious diseases, in this case the spread of a plague caused by an early form of Yersina pestis from Eastern Europe and Central Asia (RAsmussen et al., 2015; ValtueÑa et al. 2017; RAscovan et al., 2019).

According to our current knowledge, the Yamnaya communities migrated to the Great Hungarian Plain from the Lower Danube region and they advanced along the Tisza to the Upper Tisza region. The general scholarly consensus is that they occupied the trans-Tisza region; however, the excavation of the kurgan at Dusnok by Andrea Lantos and Réka Andrási, and the investigations targeting the kurgans in the Kiskunság region by Rozália Kustár, Réka Balázs and Pál Sümegi (BALÁzs, 2006; Kustár et al., 2014; BALÁzs \& KusTÁR, 2015, 30-32; 2016) have revealed that the Yamnaya pastoralists moved across the entire Hungarian Plain with their flocks and herds, and the archaeological record from Transylvania indicates that they also reached the Transylvanian Basin as shown by the sites of Câmpia Turzii (Aranyosgyéres), Cipău (Maroscsapó), Răscruci (Válaszút) and other sites (CiugudeAn, 2011, 27-29, Appendix 1: earthen tumuli, Fig. 
János Dani $•$ Kurgans and their Builders. The Great Hungarian Plain at the dawn of the Bronze Age

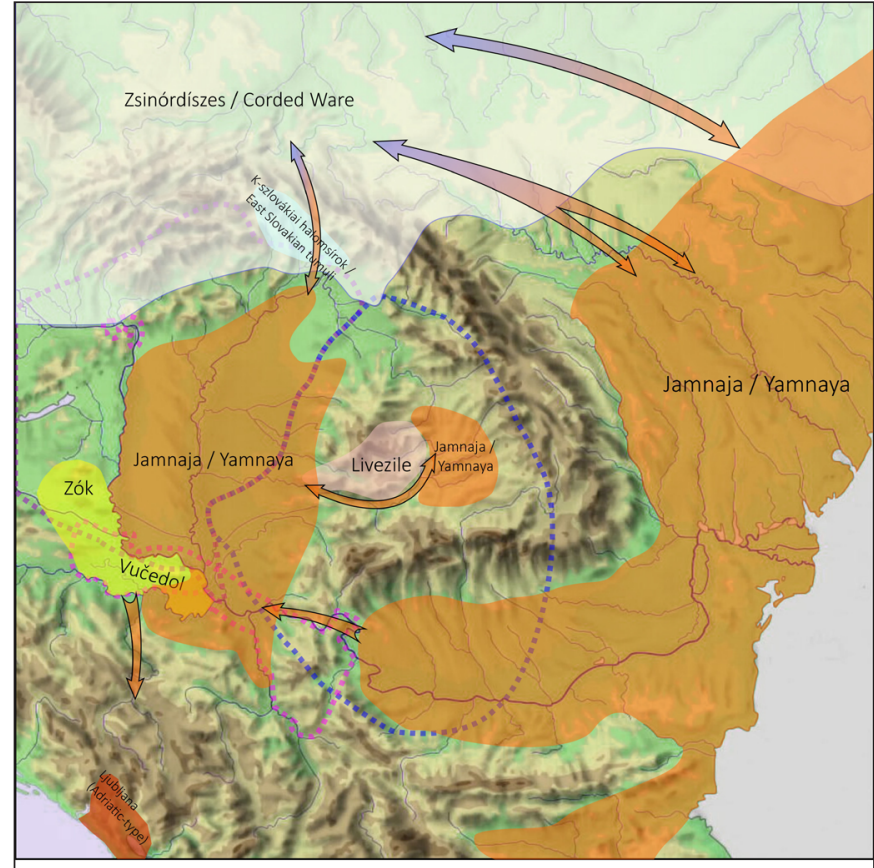

A Kárpát-medence Kr.e. 3000-2600 között /The Carpathian Basin between 3000-2600 BC

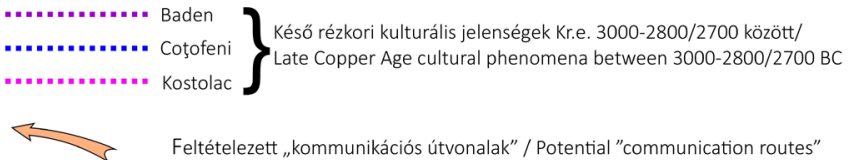

Fig. 8. Distribution of the Yamnaya culture in the Carpathian Basin and its connections (map: Z. Faur, after Włodarczak, 2014, Fig. 2, with some modifications)
1; HeYd, 2012, 538, Fig. 1; FrînCUlEasa et al., 2015, 77; Gogâltan, 2016, 422-424, Abb. 3; SzÁsz, 2017, 8) (Fig. 8). Ádám Bede's landscape archaeological studies in the Middle Trans-Tisza region based on topographic work and field surveys combined with the meticulous assessment of the relevant archival records (e.g. BEDE, 2016; 2017, for the methodology) have convincingly demonstrated that the number of kurgans recorded in various registers (Agricultural Parcel Identification System / Mezőgazdasági Parcella Azonosító Rendszer (MePAR), Landscape Value Cadastre / TájÉrték Kataszter (TÉKA), register of Cumanian mounds in national parks, register of authenticated archaeological sites) is exceeded by far by the mounds that had once dotted the landscape, but had perished during the past 2-300 years, mostly owing to human activities.

The maps showing the reconstructed kurgan fields in the area between Tiszavasvári and Hajdúnánás, and the kurgan fields along the eastern bank of the Dusnok Stream on the north-eastern outskirts of Dusnok capture the transformation of the landscape that can best be described as "kurganisation", when between 3100/3000 and $2600 \mathrm{BC}$, the appearance of enormous numbers of Yamnaya burial mounds led

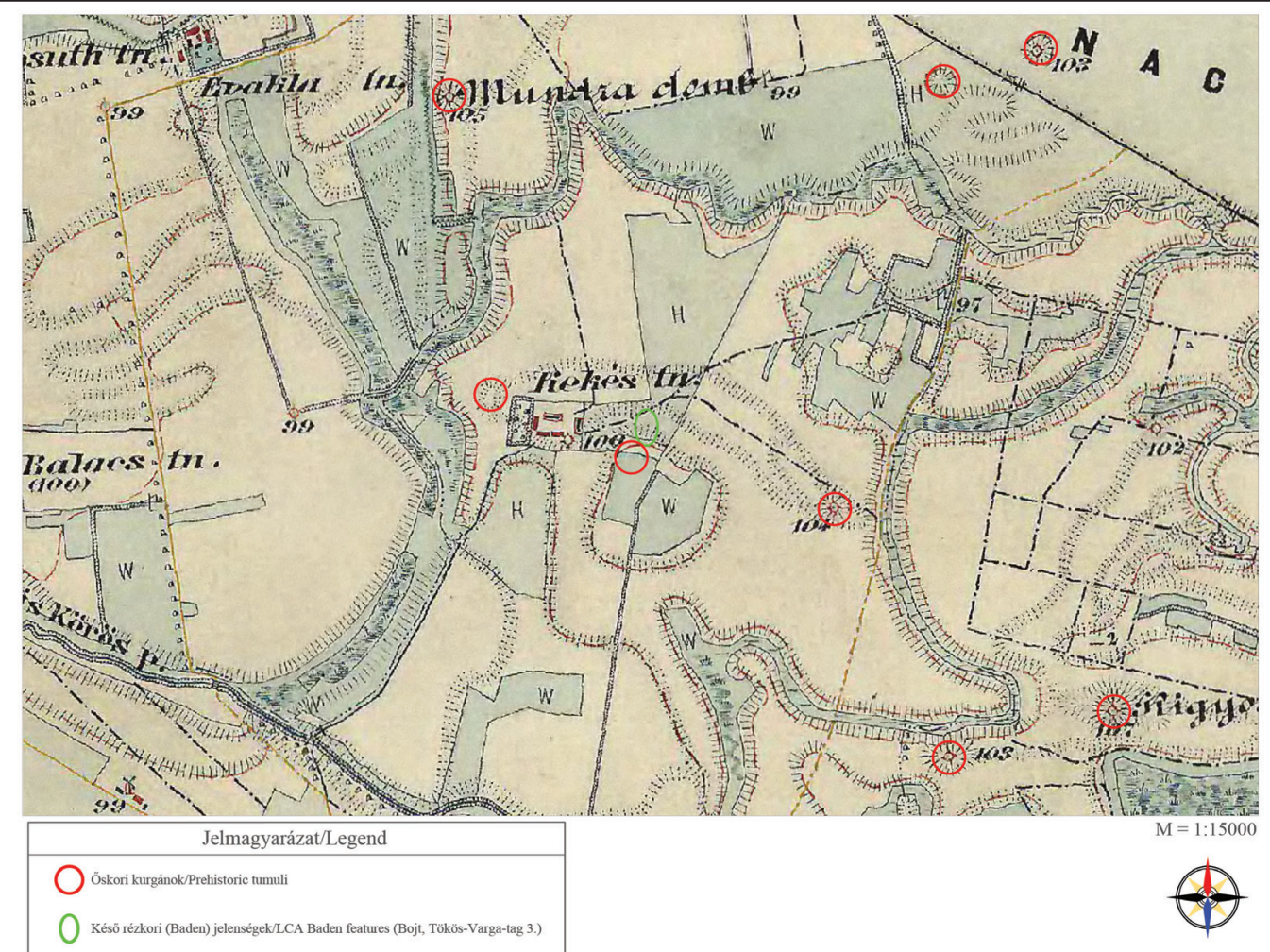

Fig. 9. The north-eastern outskirts of Bojt and the kurgans and Baden site along the Dusnok Stream on the map of the Third Military Ordnance Survey (map: T. Czirbik-Gulyás) 


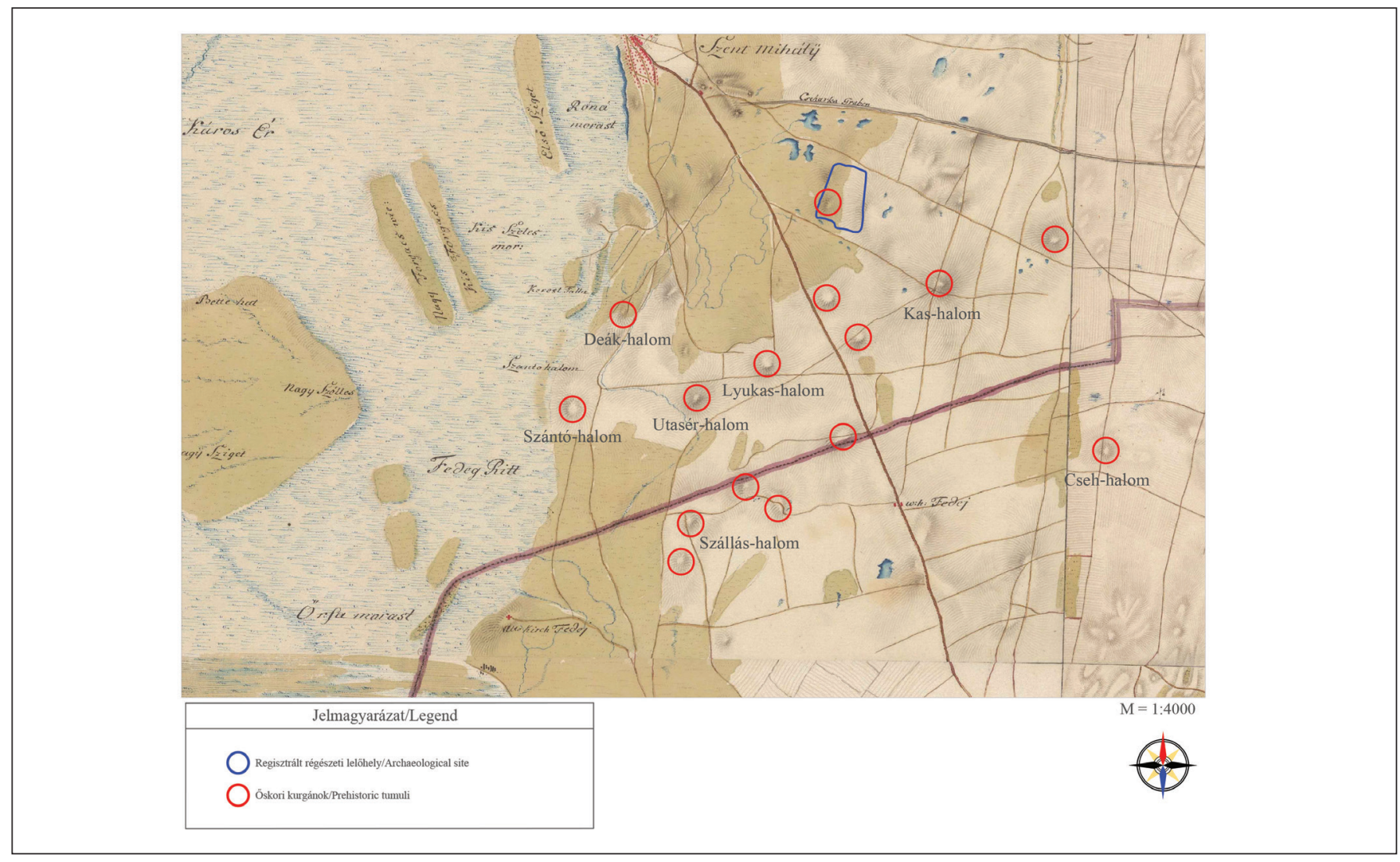

Fig. 10. The kurgans in the area between Tiszavasvári and Hajdúnánás and the Baden settlement in the Kas-halom-dülö area on the map of the First Military Ordnance Survey (map: T. Czirbik-Gulyás)

to a profound change in the landscape of the trans-Tisza region of the Great Hungarian Plain compared to how it was used during the earlier Late Copper Age Baden period (Figs 9-10).

\section{LATE YAMNAYA IMPACTS, SURVIVAL IN THE BRONZE AGE}

In the lack of sufficient and reliable data (sites and finds), it is virtually almost impossible to capture and describe in adequate detail the transition from the Late Copper Age to the Early Bronze Age in the Carpathian Basin; nevertheless, we are able to fit increasingly more pieces into the overall picture of this complex process known as the Transitional Period (Kulcsár, 2013; Kulcsár \& Szeverényi, 2013; Heyd, 2016, 62-79; Horváth,, 2016; Szabó 2017, 100-102, 108-104-105, 108, Fig. 5; REMÉNYI, 2018, 48-50). A freshly published find assemblage from Cegléd (PATAY, 2020), reflecting a unique

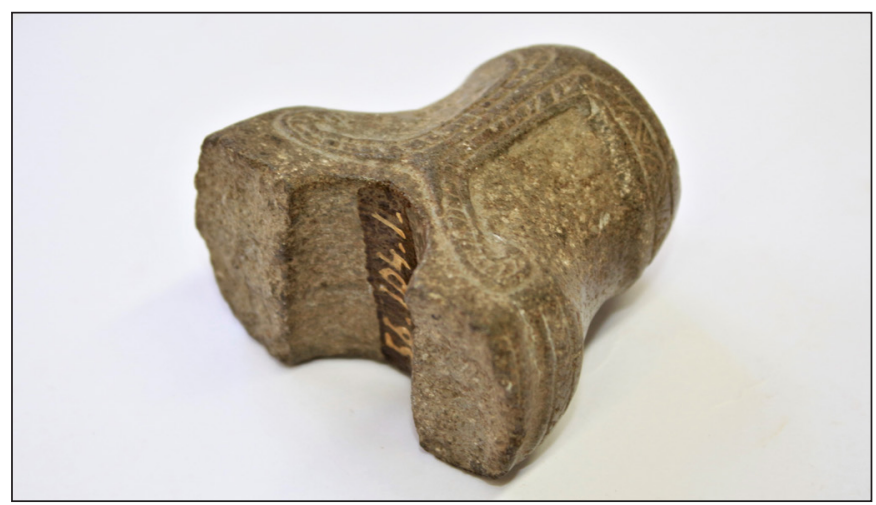

Fig. 11. Tiszaeszlár-Temetö: fragment of a lavishly ornamented polished stone axe (photo: A. Linzenbold) blend of the slowly disappearing Eastern European Yamnaya and local Late Copper Age Baden traditions and of the Vučedol impacts from the south (from the Srem region), heralds the gradual emergence of the Bronze Age (PATAY, 2020). While the Yamnaya period is followed by the Catacomb period - so named after its distinctive burials - in the northern Pontic, not one single burial of this type has yet been uncovered in Hungary, even though a handful of finds in the local Early Bronze Age material does reflect connections with the Catacomb culture. The best known among these is a stray find, the fragment of a lavishly ornamented polished stone axe from Tiszaeszlár-Temetö (Kalicz, 1968, 46, Taf. I/6; Fig. 11). 
János Dani $\bullet$ Kurgans and their Builders. The Great Hungarian Plain at the dawn of the Bronze Age

The Eastern European connections of the Early Bronze Age in the Upper Tisza region are illustrated by the finds from the kurgan excavated at Lohovo-Skorababka-dülő (Beregszőlős, Transcarpathia, Ukraine). Of the five mounds registered at this site, Fedor M. Potushniak investigated the strongly eroded largest kurgan (base diam. 28 m, H. 2 m; (РотushNIAK, 1958, 74-77, Tabl. XLV/1a-b, 8; Fig. 12). A Catacomb-type censer set on four small legs and decorated with cord impressions came to light from the kurgan's central area (KAISER, 2019, 251, Abb. 141.a; Fig. 13.1), beside which lay greyish remains, which the excavator believed to be of human origin, possible the remnants of a cremation burial. Lying some 1 $m$ south of the censer was a funnel-necked globular vessel (Fig. 13.2) recalling the vessels of the Corded Ware culture, whose main distribution lies beyond the Carpathians. A $20 \mathrm{~cm}$ deep pit with a diameter of $2 \mathrm{~m}$ containing charcoal was uncovered in the kurgan's south-eastern part, north of which there was a feature with red-burnt walls having a diameter of $1 \times$ $0.7 \mathrm{~m}$, first noted at a depth of $4 \mathrm{~cm}$ from the mound's surface, that extended to the base of the kurgan (where it narrowed to $45 \mathrm{~cm}$ ). Aside from charcoal, this feature yielded a broken obsidian blade. The formal and decorative traits of the vessels from what was probably a scattered cremation burial attest to cultural contacts resulting in a blend of the traditions of the Catacomb and Corded Ware cultures.

As shown by the above examples, the territory between the Tisza and the north-eastern Carpathian range, i.e. the river valleys of the northern Tisza catchment in south-eastern Slovakia (the Tarca / Torysa, Ondava, Tapoly / Topl'a, Laborc / Laborec and Latorca/ Latorica valleys) and the hill regions dissected by the valleys, appear to have been one potential contact zone between the Yamnaya and the Corded Ware cultural complexes. Vojtech Budinský-Krička mapped and excavated countless kur-

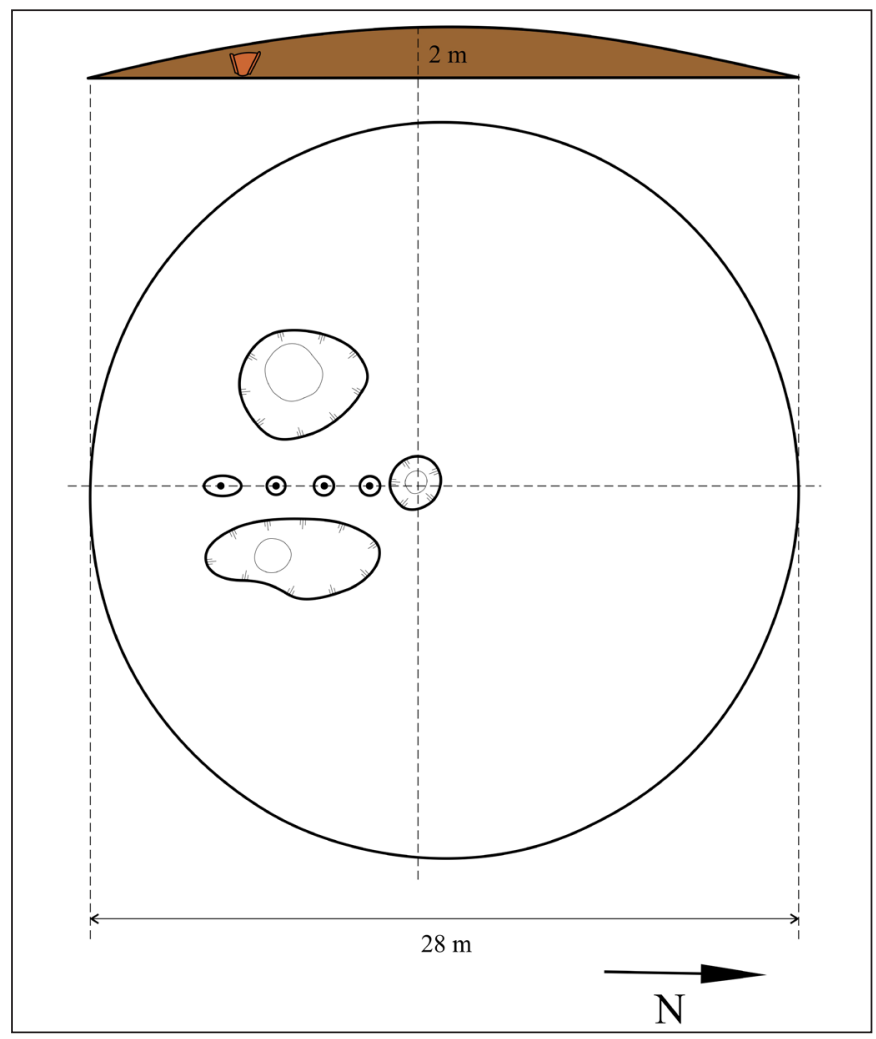

Fig. 12. Lohovo (Beregszölös, Ukraine), Skorababka-dülö: plan and section of the excavated kurgan (drawing: Z. Faur, based on Potushniak 1958, Tabl. XLV/8)

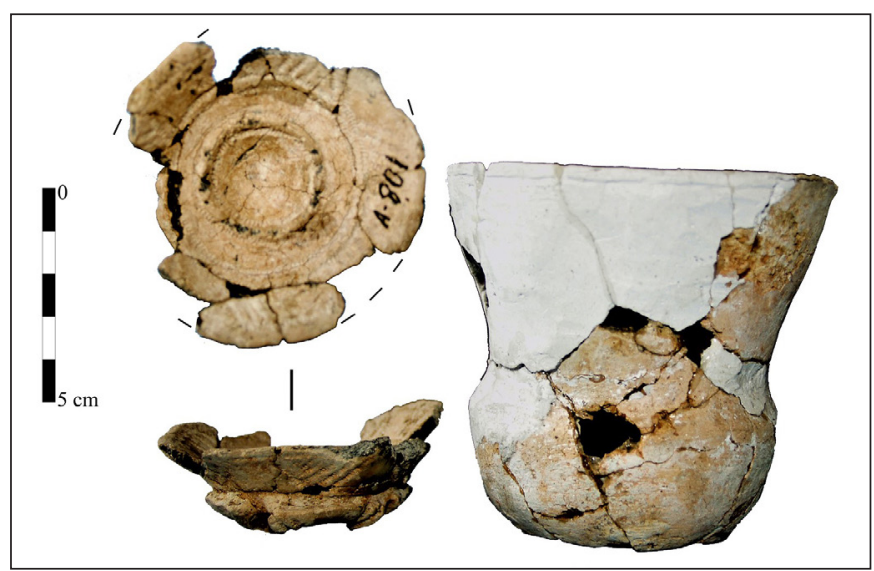

Fig. 13. Lohovo (Beregszölös, Ukraine), Skorababka-dülö: the small censer (1) and the funnel-necked vessel (2) from the excavated kurgan (photo: J. Dani) gans attributed to the group of East Slovakian tumuli of various sizes raised over inhumation or cremation burials dating from the earlier third millennium between 1940 and 1960 (JAROsZ, 2010).

Similarly, rivers valleys - principally the Maros and Körös valleys - were the main arteries of communication towards the heartland of Transylvania: it is hardly mere chance that the Yamnaya burials currently known from Transylvania lie along the Maros and that the southern and eastern regions of the Transylvanian Apuseni Mountains bordering on the Maros valley were occupied by Livezile groups, whose mortuary practices involved raising stone-packed mounds over their dead. The Livezile sites often overlie those of the local Late Copper Age Coţofeni culture (Ciugudean, 2011, 23-27, Fig. 1).

Aside from the "genetic imprint" of the Yamnaya groups settling in the Carpathian Basin, the perhaps most striking impact is the appearance and spread of the custom of raising mounds over burials among the 
János Dani $\bullet$ Kurgans and their Builders. The Great Hungarian Plain at the dawn of the Bronze Age

contemporaneous cultures and those of the ensuing Early Bronze Age. A distinctive syncretism has been documented in the kurgan burials of the Vučedol culture at Batajnica-Velika humka and Vojka-Humka in the Belgrade area, where the primary burial was an inurned cremation grave with Vučedol vessels (TAsić, 1995, 16, 72-73, 74, 79, Pl. XXXI/6; Miloglav, 2018, 131), similarly as at Moldova Veche on the Romanian bank of the Danube (RomAn, 1976, 17, 32, P1. 19/a-d; 1980, 224, note 35). In the Kotor area on the Adriatic coast, we find a series of "royal" kurgans such as the ones investigated at Gruda Boljevica, Mogila na Rake, Kujava, Rubeža, Mala Gruda and Velika Gruda dating from 2900-2700 BC, all richly furnished burials of the Adriatic type known for its sophisticated and lavishly ornamented vessels, the local variant of the Ljubljana culture, which was related to Vučedol (GovEDARICA, 2018). The next period, hallmarked by the communities of the Somogyvár-Vinkovci, Livezile (western Transylvanian tumular group) and Şoimuş and of the East Slovakian tumuli, saw the internment of the dead under burial mounds (BÁtorA, 2012; HeYd, 2012; Fig. 8).

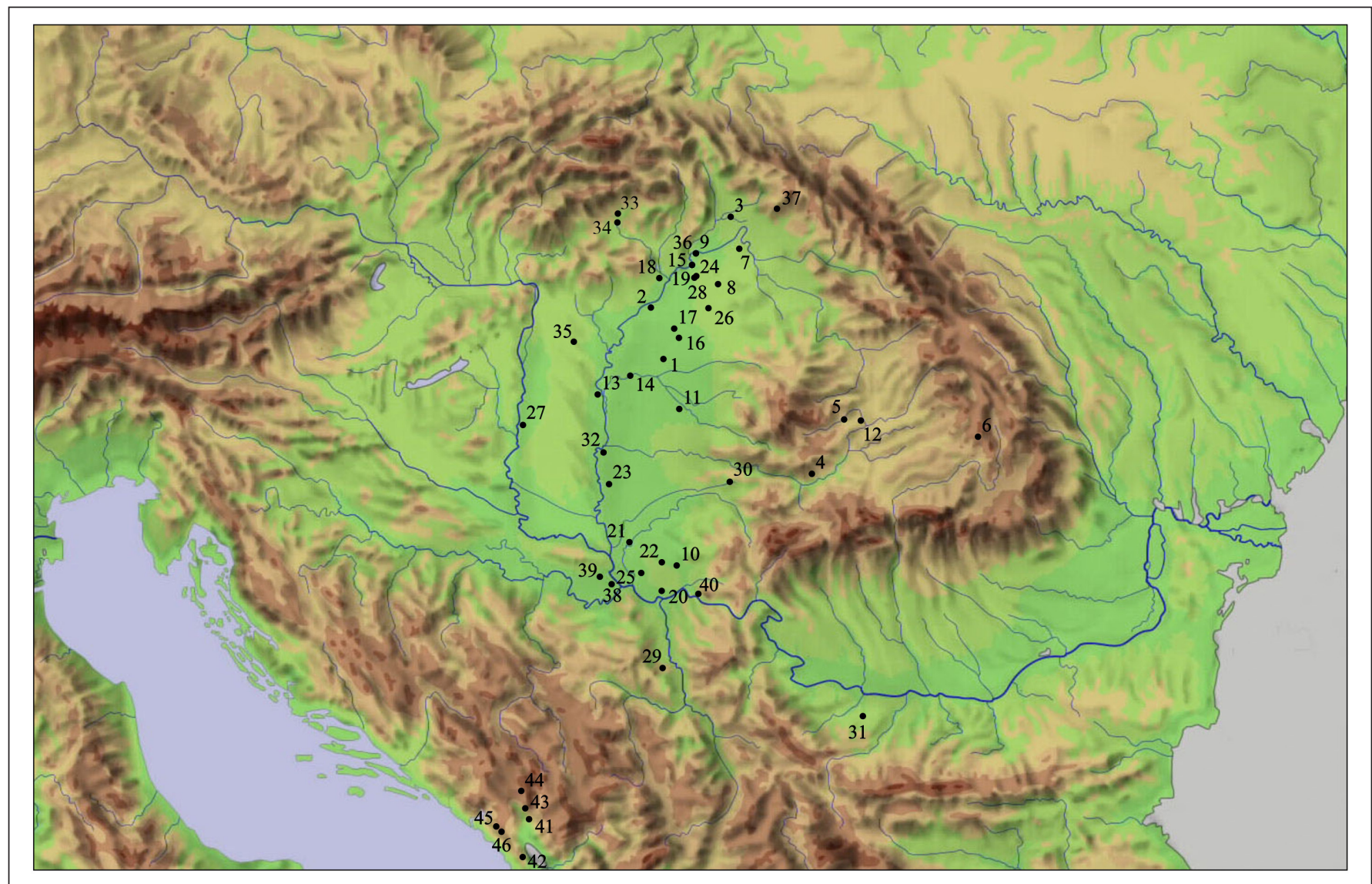

Fig. 14. Kurgan sites. Research history / Early kurgan excavations: 1 - Dévaványa-Templomdombon; 2 - Tiszaigar-Kettöshalom;

3 - Král'ovský Chlmec (Királyhelmec), Erös erdö (Slovakia); 4 - Carpenii de Sus (Gyertyános) (Romania); 5 - Izvoarele

(Bedellö) (Romania); 6 - Ocland (Oklánd) (Romania); 7 - Nyírkarász-Garahalom; 8 - Geszteréd, Kurgan A; 9 - Tiszaeszlár-

Potyhalom and Bashalom; 10 - Ulma (Homokszil) (Serbia); 11 - Kétegyháza, Kigyós-puszta kurgan field (between Kétegyháza and Békéscsaba). First Eastern European impacts: 12 - Decea Mureşului (Marosdécse) (Romania); 13 - Csongrád-Kettőshalom,

Bárdos-tanya. Pre-Yamnaya period in Hungary: 14 - Békésszentandrás, Nádas-halom; 15 - Tiszavasvári-Deákhalom;

16 - Sárrétudvari-Örhalom; 17 - Püspökladány-Kincsesdomb. Yamnaya vs. Baden/Coţofeni: 18 - Mezöcsát-Hörcsögös;

19 - Tiszavasvári-Gyepáros; 20 - Skorenovac (Serbia); 21 - Perlez (Perlesz) - Batka C (Serbia); 22 - Pašića Humka (Serbia);

23 - Padej (Padé)-Barnahát (Serbia); 24 - Hajdúnánás-Zagolya; 25 - Jabuka (Torontálalmás) -Tri Humke (Serbia);

26 - Debrecen-Ohat, Dunahalom; 27 - Dusnok, Garáb-halom; 28 - Hajdúnánás-Tedej, Lyukas-halom; 29 - Kragujevac, Bare kurgan (Serbia); 30 - Bodo (Banat, Romania); 31 - Trnava (Tърнавa), Kurgan 2 (Glavcovska mogila) (Vratsa region, Bulgaria); 32 - Sprski Krstur (Ókeresztúr/Szerbkeresztúr), Slatinska humka (Serbia). Tumulus burials of the Baden culture: 33 - Gemer

(Sajógömör) (Slovakia); 34 - Včelince (Méhi) (Slovakia). Late Yamnaya and Catacomb period: 35 - Cegléd, Site 4/4;

36 - Tiszaeszlár-Temetö; 37 - Lohovo (Beregszölös, Transcarpathian region, Ukraine), Skorababka-dülö. Kurgan burials of the

Vučedol culture: 38 - Batajnica-Velika humka (Serbia); 39 - Vojka-Humka (Serbia); 40 - Moldova Veche (Romania). "Royal” kurgans of the Ljubljana culture (Adriatic type): 41 - Gruda Boljevica (Montenegro); 42 - Mogila na Rake (Montenegro); 43 - Kujava (Montenegro); 44 - Rubeža (Montenegro); 45 - Mala Gruda (Montenegro); 46 - Velika Gruda (Montenegro) 


\section{THE HUMAN FACTOR}

It is less known that in their study on the human remains from the Csongrád-Kettőshalom and other kurgans, Antónia Marcsik and Zsuzsanna K. Zoffmann had pointed out over fifty years ago that a "new" anthropological type of Eastern European stock (the tall Cromagnoid A type with high robusticity) appeared in the Carpathian Basin during the Copper Age (MarcsiK, 1974; 1979; K. Zoffmann, 1978; 2006; 2011). The growing number of archaeogenetic analyses performed during the past ten years wholly confirmed the findings of earlier physical anthropological studies and highlighted the appearance and rapid diffusion of the steppean Yamnaya ethnic groups across the greater part of Europe (AllENTOFT et al., 2015; HAAK et al., 2015; Olalde et al., 2018). As a global process, the Yamnaya migration most likely lasted for a longer period of time and not only towards western Europe, but also towards southern Siberia (the northern foreground of the Altai), leading to the formation of the Afanasyevo culture (Bower, 2017, "Big moves" map, 6-7; cf. also BARRos DAMGAARD et al., 2018). It would appear that this migration was made up of several successive waves: communities of various sizes split off from the pastoral Yamnaya groups of the Eurasian steppe belt and advanced towards the Balkans and the Carpathian Basin as well as towards Inner Asia. Besides genetic studies, stable isotope analyses $\left({ }^{87} \mathrm{Sr} /{ }^{86} \mathrm{Sr} ; \delta^{18} \mathrm{O}\right)$ are another important source of information regarding the mobility of pastoral groups: the light isotope analyses of the secondary burials of the Sárrétudvari-Örhalom kurgan shed light on a traditional transhumance route - also underpinned by the archaeological and ethnographic record - between the westerly regions of the Apuseni Mountains and the Bihar Sárrét region (GerLING et al., 2012a; 2012b; DANI 2014).

In addition to the assessment of the genetic samples of the Yamnaya communities of the Carpathian Basin, currently still in progress, the ${ }^{15} \mathrm{~N}$ and ${ }^{13} \mathrm{C}$ light isotope analyses also reveal much about the lifeways and diet of these communities. While stable isotope analyses provide information on more general tendencies, the study of dental calculus, a new research direction introduced by Zsuzsa Lisztes-Szabó in the Hertelendi Laboratory of Environmental Studies of Debrecen, provides exciting new data on the dietary habits of pastoralists based on phytoliths and micro-remains conserved in dental calculus.

The goal of a new ERC-funded project led by Prof. Volker Heyd, "The Yamnaya Impact on Prehistoric Europe (YMPACT)" launched in 2019, is to gain a better understanding of the connections and lifeways of the westernmost Yamnaya communities as well as of the local and global impact of their appearance. The novel directions and many new approaches in this field of research is illustrated by the case study on a young woman interred in the primary burial of a destroyed kurgan investigated at the site Bojt-TökösVarga-tag 3 (HEYD et al., 2020).

\section{EPILOGUE}

The impact of the nomadic Yamnaya communities of Eastern European stock on other European regions is strongly intertwined with the many still unresolved issues of Indo-European migrations and the origins of the currently spoken Indo-European tongues that have always commanded scholarly attention and have repeatedly sparked heated debates (Anthony \& Ringe, 2015; Heyd, 2017; Anthony \& Brown, 2017; KLEJN, 2017; KLEJN et al., 2017; KRISTIANSEN et al., 2017, LAZIRIDIS, 2018). This controversial issue can hardly be resolved by archaeology, linguistics or genetic studies alone - only complex interdisciplinary studies will be able to provide meaningful answers to the question of the Indo-Europeanisation of the European continent (Anthony, 2019; Koch, 2019; Kozintsev, 2019).

\section{BIBLIOGRAPHY}

Allentoft, M. E., Sikora, M., Sjögren, K.-G., Rasmussen, S., Rasmussen, M., et al. (2015). Population genomics of Bronze Age Eurasia. Nature 522, 167-172. https://doi.org/10.1038/nature14507 
János Dani $\bullet$ Kurgans and their Builders. The Great Hungarian Plain at the dawn of the Bronze Age

Anthony, D. (2007). The Horse, the Wheel and Language. How Bronze Age riders from the Eurasian steppes shaped the modern world. Oxford: Princeton University Press, Princeton and Oxford.

Anthony, D. W. (2017). Archaeology and Language: Why Archaeologists Care about the Indo-European Problem. In P. J. Crabtree \& P. Bogucki (eds.), European Archaeology as Anthropology: Essays in Memory of Bernard Wailes (pp. 39-69). Philadelphia: University of Pennsylvania Press.

Anthony, D. W. (2019). Ancient DNA, Mating Networks, and the Anatolian Split. In M. Serangeli \& Th. Olander (eds.), Dispersals and Diversification. Linguistic and Archaeological Perspectives on the Early Stages of Indo-European (pp. 21-53). Brill's Studies in Indo-European Languages \& Linguistics, Vol. 19. Leiden: Brill. https://doi.org/10.1163/9789004416192 003

Anthony, D. W. \& Brown, D. R. (2017). Molecular Archaeology and Indo-European linguistics: Impressions from new data. In B. Simmelkjær, S. Hansen, A. Hyllested, A. R. Jørgensen \& G. Kroonen (eds.), Usque ad Radices: Indo-European Studies in Honour of Birgit Anette Olsen. Copenhagen: Museum Tusculanum Press.

Anthony, D. W. \& Ringe, D. (2015). The Indo-European homeland from linguistic and archaeological perspectives. Annual Review of Linguistics 1, 199-219. https://doi.org/10.1146/annurev-linguist-030514-124812

Balázs, R. (2006) A kunhalmok kataszterezésének tapasztalatai a Kiskunsági Nemzeti Park Igazgatóság müködési területén [Inventorying Cumanian mounds in the Kiskunság National Park]. In A. Kiss, G. Mezősi \& Z. Sümeghy (eds.), Táj, környezet és társadalom. Ünnepi tanulmányok Keveiné Bárány Ilona professzor asszony tiszteletére (pp. 69-77). Szeged: SZTE Éghajlattani és Tájföldrajzi Tanszék - SZTE Természeti Földrajzi és Geoinformatikai Tanszék.

Balázs, R. \& Kustár, R. (2015). Halmok az évszázadok sodrában. Halmok, hegyek és várak a Duna-Tisza közén [Mounds through the centuries. Mounds, hills and forts in the Danube-Tisa Interfluve]. Kecskemét: Kiskunsági Nemzeti Park Igazgatóság.

Balázs, R. \& Kustár, R. (2016). Halmok az évszázadok sodrásában - halmok, földvárak természetközeli állapotba való visszaállítása a Duna-Tisza közén [Mounds through the centuries - restoring the natural condition of mounds and earthworks in the Danube-Tisa Interfluve region]. In G. Horváth (ed.), Tájhasználat és tájvédelem-Kihívások és lehetöségek. A Budapesten 2015. május 21-23. között megrendezett VI. Magyar Tájökológiai Konferencia elöadásainak kivonatai (p. 14). Budapest: ELTE, Földrajz- és Földtudományi Intézet, Környezet és Tájföldrajzi Tanszék.

Barras, C. (27 March 2019). Story of most murderous people of all time revealed in ancient DNA. New Scientist. https://www.newscientist.com/article/mg24132230-200-story-of-most-murderous-people-of-alltime-revealed-in-ancient-dna/\#ixzz6NR3zqi2v Accessed: 2 June 2020.

de Barros Damgaard, P., Martiniano, R., Kamm, J., Moreno-Mayar, J. V., Kroonen, G., et al. (29 June 2018). The first horse herders and the impact of early Bronze Age steppe expansions into Asia. Science 360 (6396), eaar7711. https://doi.org/10.1126/science.aar7711

Bátora, J. (2012). Bestattungen unter Hügeln im Gebiet der mittleren Donau seit dem Ende des Äneolithikums bis zum Beginn der mittleren Bronzezeit. In E. Borgna \& S. Müller Cerka (eds.), Ancestral Landscapes. Burial Mounds in the Copper and Bronze Ages (Central and Eastern Europe-Balkans - Adriatic-Aegean, 4th-2nd millennium B. C.). Proceedings of the International Conference held in Udine, May 15th-18th 
János Dani $\bullet$ Kurgans and their Builders. The Great Hungarian Plain at the dawn of the Bronze Age

2008 (pp. 87-96). Travaux de la Maison de l'Orient et de la Méditerranée. Série recherches archéologiques 58. Lyon: Maison de l'Orient et de la Méditerranée Jean Pouilloux.

Bede, Á. (2016). Kurgánok a Körös-Maros vidékén... Kunhalmok tájrégészeti és tájökológiai vizsgálata a Tiszántúl középső részén [Mounds in the Körös-Maros region... A landscape archaeological and landscape ecological study of Cumanian mounds in the middle of the Transtisza region]. Budapest: Magyar Természettudományi Társulat.

Bede, Á. (2017). Halomkataszterezési munkálatok a Tiszántúl középső részén (Cadastral field surveys on mounds in the central part of the Tiszántúl region, Hungary). In E. Benkő, M. Bondár \& Á. Kolláth (eds.), Magyarország Régészeti Topográfiája. Múlt, jelen, jövö. Archaeological Topography of Hungary - Past, Present and Future (pp. 45-66). MTA Bölcsészettudományi Kutatóközpont Régészeti Intézet Archaeolingua.

Bede, Á., Czukor, P., Csathó, A. I. \& Sümegi, P. (2019). Adatok a kétegyházi két Török-halom tájtörténetéhez (Data for the landscape history of the two Török-halom kurgans in Kétegyháza [Hungary]). Földrajzi Közlemények 143 (4), 358-373.

Bower, B. (25 November 2017). How Asian nomadic herders built new Bronze Age cultures. In wagons and on horses, Yamnaya pastoralists left their genetic mark from Ireland to China. Science News 192 (9). https://www.sciencenews.org/article/how-asian-nomadic-herders-built-new-bronze-age-cultures Acessed: 2 June 2020.

Bukvić, L. (1979). Results of the researches of the mound near Jabuka. A contribution to the study of the culture of graves under tumuli. Archaeologia Iugoslavica 19, 14-18.

Bulatović, A. (2014). Corded ware in the Central and Southern Balkans: A consequence of cultural interaction or an indication of ethnic change? Journal of Indo-European Studies 42 (1-2), 101-143.

Ciugudean, H. (2011). Mounds and Mountains: Burial rituals in Early Bronze Age Transylvania. In S. Berecki, R. E. Németh \& B. Rezi (eds.), Bronze Age Rites and Rituals in the Carpathian Basin. Proceedings of the international colloquium from Târgu Mureş 8-10 October 2010 (pp. 21-57). Târgu Mureş: Editura Mega.

Dani, J. (2011). Research of Pit-Grave Culture Kurgans in Hungary in the Last Three Decades. In Á. Pető \& A. Barczi (eds.), Kurgan Studies: An Environmental and Archaeological Multiproxy Study of Burial Mounds in the Eurasian Steppe Zone (pp. 25-69). British Archaeological Reports International Series 2238. Oxford: Archaeopress.

Dani, J. (2014). (Too) much ado, about (almost) nothing. A Debreceni Déri Múzeum Évkönyve 85, 23-27.

Dani, J., Márkus, G., Kulcsár, G., Heyd, V., Włodarczak, P., Zitnan, A. \& Peška, J. (2017). A „Yamnaya Impact Project" régészeti topográfiai tanulságai - Archaeological topographic results of the "Yamnaya Impact Project”. In E. Benkő, M. Bondár \& Á. Kolláth (eds.), Magyarország régészeti topográfiája: Múlt, jelen, jövö - Archaeological Topography of Hungary: Past, Present and Future (pp. 137-150). Budapest: MTA Bölcsészettudományi Kutatóközpont Régészeti Intézet - Archaeolingua.

Dani, J. (2020 in press). Milleker’s pride and joy. In P. Włodarczak (ed.), Dunajski szlak kultury jamowej (Danubian Route of the Yamnaya culture). Kraków. 
János Dani $\bullet$ Kurgans and their Builders. The Great Hungarian Plain at the dawn of the Bronze Age

Dergachev, V. А. (Дергачёв, В. А.) (2007). O skipetrah, o loshadjah, o vojne. Jetjudyvzashhitu migracionnoj koncepcii M. Gimbutas (О скипетрах, о лошадях, о войне. Этюды в защиту миграционной концепции М. Гимбутас) [On sceptres, horses, wars. In defence of the migration theory of M. Gimbutas]. St. Petersburg: Nestor-Historia.

Ecsedy, I. (1973). Újabb adatok a tiszántúli rézkor történetéhez. (New data on the history of the Copper Age in the region beyond the Tisza). A Békés Megyei Múzeumok Közleményei 2, 3-40.

Ecsedy, I. (1979). The People of the Pit-Grave Kurgans in Eastern Hungary. Fontes Archaeologici Hungariae. Budapest: MTA BTK Régészeti Intézet.

Fenichel, S. (1891a). Gyertyánosi és bedelői halomsírokról [About the tumuli in Gyertyános and Bedelö]. Archaeológiai Értesitö 11, 65-69.

Fenichel, S. (1891b). A bedelői „la furcsi” határbeli tumulusok [The tumuli in the "la furcsi” region of Bedelő]. Archaeológiai Értesítö 11, 160-163.

Frenyó, P. (1889). A dévaványai „templomdombról” [About the “church hill” of Dévaványa]. Archaeológiai Értesitö 9, 53-57.

Frînculeasa, A., Preda, B. \& Heyd, V. (2015). Pit-graves, Yamnaya and kurgans at the Lower Danube: Disentangling 4th and 3rd millennium BC burial customs, equipment and chronology. Praehistorische Zeitschrift 90 (1-2), 45-113. https://doi.org/10.1515/pz-2015-0002

Garašanin, M. V. (1959). Neolithikum und Bronzezeit in Serbien und Makedonien. Überblick über den Stand der Forschung 1958. Bericht der Römisch-Germanischen Kommission 39, 1-130.

Gerling, C., Bánffy, E., Dani, J., Köhler, K., Kulcsár, G., et al. (2012a). Yamnaya migration and transhumance in the Early Bronze Age Carpathian Basin: the occupants of a kurgan. Antiquity 86, 1097-1111. https://doi. org/10.1017/S0003598X00048274

Gerling, C., Heyd, V., Pike, A. W. G., Bánffy, E., Dani, J., et al. (2012b). Identifying Kurgan Graves in Eastern Hungary - A Burial Mound in the Light of Strontium and Oxygen Isotope Analysis. In E. Kaiser (ed.), Population Dynamics in Prehistory and Early History: New Approaches Using Stable Isotopes and Genetics (pp. 165-176). Berlin: De Gruyter Verlag. https://doi.org/10.1515/9783110266306.165

Girić, M. (1982). Über die Erforschung der Grabhügel in der Wojwodina. In A. Aspes \& L. Fasani (eds.), Il passaggio dal neolitico all 'età del bronzo nell'Europa centrale e nella regione Alpina: problemi cronologici e terminologici: atti del X Simposio internazionale sulla fine del Neolitico e gli inizi dell'età del Bronzo in Europa, Lazise - Verona 8-12 aprile 1980 (pp. 99-105). Verona: Museo Civico di Storia Naturale.

Girić, M. (1987). Die Erforschung der äneolitischen Hügelgräber im nördlichen Banat. In D. Srejović \& N. Tasić (Hrsg. von), Hügelbestattung in der Karpaten-Donau-Balkan-Zone während der äneolithischen Periode. Internationales Symposium Donji Milanovac 1985 (pp. 71-76). Beograd: Balkanološki Institut SANU.

Gogâltan, F. (2011). Die Beziehungen zwischen Siebenbürgen und dem Schwarzmeerraum. Die ersten Kontakte (ca. 4500-3500 v. Chr.). In E. Sava, B. Govedarica \& B. Hänsel (Hrsg.), Der Schwarzmeerraum vom Äneolithikum bis in die Früheisenzeit (5000-500 v. Chr.), Band 2: Globale Entwicklung versus Lokalgeschehen. Internationale Fachtagung von Humboldtianern für Humboldtianer im Humboldt-Kolleg 
János Dani $•$ Kurgans and their Builders. The Great Hungarian Plain at the dawn of the Bronze Age

in Chişinău, Moldavien (4-8. Oktober 2010) (pp. 101-124). Prähistorische Archäologie in Südosteuropa 27. Rahden: Leidorf.

Gogâltan, F. (2013). Transilvania şi spaţiul nord-pontic. Relaţii interculturale între sfârşitul epocii cuprului şi începutul epocii bronzului (cca. 3500-2500 a. Chr.) (Die Beziehungen zwischen Siebenbürgen und dem Schwarzmeerraum in der Kupfer- und am Anfang der Bronzezeit (cca. 3500-cca. 2500 v. Chr.). Terra Sebus. Acta Musei Sabesiensis 5, 31-76.

Gogâltan, F. (2016). Die Beziehungen zwischen Siebenbürgen und dem Schwarzmeerraum in der Kupferund am Anfang der Bronzezeit (ca. 3500 - ca. 2500 v. Chr.). In V. Nikolov \& W. Schier (Hrsg.), Der Schwarzmeerraum vom Neolithikum bis in die Früheisenzeit (6000-600 v. Chr.). Kulturelle Interferenzen in der zirkumpontischen Zone und Kontakte mit ihren Nachbargebieten (pp. 417-447). Prähistorische Archäologie in Südosteuropa Bd. 30. Rahden: Leidorf.

Govedarica, B. (2004). Zepterträger - Herrscher der Steppen. Die frühen Ockergräber des älteren Äneolithikums im karpatenbalkanischen Gebiet und im Steppenraum Südost- und Osteuropas. Heidelberger Akademie der Wissenschaften Internationale Interakademische Kommission für die Erforschung der Vorgeschichte des Balkans. Heidelberger Akademie der Wissenschaften. Internationale Interakademische Kommission für die Erforschung der Vorgeschichte des Balkans Band 6. Mainz: Zabern.

Govedarica, B. (2018). Kneževski grobovi iz Crne Gore (Princely graves from Montenegro). Podgorice: JU Muzeji i galerije Podgorice.

Govedarica, B. \& Kaiser, E. (1996). Die äneolithischen abstrakten und zoomorphen. Steinzepter Südostund Osteuropas. Eurasia Antiqua 2, 59-103.

Haak, W., Lazaridis, I., Patterson, N., Rohland, N., Rohland, N., et al. (2015). Massive migration from the steppe was a source for Indo-European languages in Europe. Nature 522 (7555), 207-211. https://doi. org/10.1038/nature14317

Heyd, V. (2012). Yamnaya groups and tumuli west of the Black Sea. In E. Borgna \& S. Müller Cerka (eds.), Ancestral Landscapes. Burial Mounds in the Copper and Bronze Ages (Central and Eastern EuropeBalkans-Adriatic-Aegean, 4th-2nd millennium B. C.). Proceedings of the International Conference held in Udine, May 15th-18th 2008 (pp. 535-555). Travaux de la Maison de l'Orient et de la Méditerranée. Série recherches archéologiques 58. Lyon: Maison de l’Orient et de la Méditerranée Jean Pouilloux.

Heyd, V. (2016). Das Zeitalter der Ideologien: Migration, Interaktion und Expansion im prähistorischen Europa des 4. und 3. Jahrtausends v. Chr. In M. Furholt, R. Großmann \& M. Szmyt (eds.), Transitional Landscapes? The 3rd Millenium BC in Europe. Proceedings of the International Workshop "SocioEnvironmental Dynamics over the Last 12,000 Years: The Creation of Landscapes III (15th - 18th April 2013)" in Kiel (pp. 53-85). Bonn: Habelt.

Heyd, V. (2017). Kossinna’s smile. Antiquity 91 (356), 348-359. http://doi.org/10.15184/aqy.2017.21

Heyd, V., Dani, J., Kulcsár, G., Hajdu, T., Lisztes-Szabó, Zs., et al. (2020). Being a Young Yamnaya Woman. Ancient DNA, stable isotopes, bio-anthropology and archaeology shed light on the life of a 4600 years old burial from Bojt (Hungary). In Individuals, Communities, Narratives. The State of Biosocial Archaeology in the Middle Danube Region. 18-19 March 2020, ELTE - Eötvös Loránd University, Budapest. Conference Abstracts (p. 11). Budapest: Eötvös Loránd Tudományegyetem. 
János Dani $\bullet$ Kurgans and their Builders. The Great Hungarian Plain at the dawn of the Bronze Age

Horváth, T. (2006). A badeni kultúráról - rendhagyó módon. (About Baden Culture - an irregular approach). A nyíregyházi Jósa András Múzeum Évkönyve 48, 89-134.

Horváth, T. (2016). 4000-2000 BC in Hungary: The Age of Transformation. In C. I. Popa (ed.), The Carpatian Basin and the Northern Balkans between 3500 and 2500 BC: Common Aspects and Regional Differences (pp. 51-112). Annales Universitatis Apulensis Series Historica 20/II. Alba Iulia: Editura Mega.

Jarosz, P. (2010). Východoslovenské mohyly - kilka uwag w oparciu o analizę materiałów źródłowych. (Východoslovenské mohyly - ein paar Bemerkungenin Anlehnung an die Quellenanalyse). In S. Czopek \& S. Kadrow (eds.), Mente et rutro. Studia archaeologica Johanni Machnik viro doctissimo octogesimo vitae anno ab amicis, collegis et discipulis oblate (pp. 275-287). Rzeszów: Instytut Archeologii Uniwersytetu Rzeszowskiego.

Jósa, A. (1897). Szabolcsmegyei őshalmok [Ancient mounds in Szabolcs County]. Archaeologiai Értesitö $17,318-325$.

Jósa, A. (1915). Ásatások a gávai Katóhalmon és környékén [Excavations in the Kató hill in Gáva and in its environs]. Archaeologiai Értesítö 35, 197-210.

Jovanović, B. (1992). Chronological relations of Late Aeneolithic of the Central and Eastern Balkans. Balcanica 23 (Hommage a Nikola Tasić a l'occasion de ses soixante ans), 243-253.

K. Zoffmann, Zs. (1978). Das anthropologische Material der Ockergräber-Bestattung von SzentesBesenyőhalom. A Móra Ferenc Múzeum Évkönyve 1976-77, 39-40.

K. Zoffmann, Zs. (2000). Anthropological sketch of the prehistoric population of the Carpathian Basin. Acta Biologica Szegediensis 44 (1-4), 75-79.

K. Zoffmann, Zs. (2006). Anthropological finds of the Pit Grave Culture from the Sárrétudvari-Örhalom site. Communicationes Archaeologicae Hungariae 2006, 51-58.

K. Zoffmann, Zs. (2011). Human remains from the kurgan at Hajdúnánás-Tedej-Lyukashalom and an anthropological outline of the Pitgrave ethnic groups. In Á. Pethő \& A. Barczi (eds.), Kurgan Studies An Environmental and Archaeological Multiproxy Study of Burial Mounds in the Eurasian Steppe Zone (pp. 173-181). British Archaeological Reports International Series 2238. Oxford: Archaeopress. https://doi. org/10.30861/9781407308029

Kaiser, E. (2019). Das dritte Jahrtausend im osteuropäischen Steppenraum. Kulturhistorische studien zu prähistorischer subsistenzwirtschaft und interaktion mit benachbarten Räumen. Berlin Studies of the Ancient World 37. Berlin: Edition Topoi. http://dx.doi.org/10.17171/3-37

Kalicz, N. (1968). Die Frühbronzezeit in Nordost-Ungarn. Abriss der Geschichte des 19-16. Jahrhunderts v. u. Z. Archaeologia Hungarica 45. Budapest: Akadémiai Kiadó.

Kalicz, N. (1999). A késő rézkori badeni kultúra temetője Mezőcsát-Hörcsögösön és TiszavasváriGyepároson. (Das Gräberfeld der spätkupferzeitlichen Badener Kultur in Mezőcsát-Hörcsögös und in Tiszavasvári-Gyepáros). A Herman Ottó Múzeum Évkönyve 37, 57-101.

Klejn, L. (2017). The steppe hypothesis of Indo-European origins remains to be proven. Acta Archaeologica 88 (1), 193-203. https://doi.org/10.1111/j.1600-0390.2017.12184.x 
János Dani $\bullet$ Kurgans and their Builders. The Great Hungarian Plain at the dawn of the Bronze Age

Klejn, L. S., Haak, W., Lazaridis, I., Patterson, N., Reich, D., et al. (2017). Discussion: Are the origins of Indo-European languages explained by the migration of the Yamnaya culture to the West? European Journal of Archaeology 21 (1), 3-17. http://doi.org/10.1017/eaa.2017.35

Koch, J. T. (2019). Formation of the Indo-European Branches in the light of the Archaeogenetic Revolution. Draft [19.03.2019] of paper read at the conference 'Genes, Isotopes and Artefacts. How should we interpret the movement of people throughout Bronze Age Europe?' Austrian Academy of Sciences, Vienna, 13-14 December 2018. https://www.academia.edu/38336128/Formation of the Indo-European branches in the light of the Archaeogenetic Revolution Accessed: 3 June 2020.

Kovács, B. Š. (1987). Hügelgräberfelder der Badener Kultur im Slanátal. Vorläufige Bemerkungen zum Bestattungsritus und Chronologie. In D. Srejović \& N. Tasić (Hrsg.), Hügelbestattung in der KarpatenDonau-Balkan-Zone während der äneolithischen Periode. Internationales Symposium Donji Milanovac 1985 (pp. 99-105). Beograd: Balkanološki Institut SANU.

Kovács, St. (1932). Cimitirul eneolitic de la Decea Mureşului [The Eneolithic cemetery of Decea Mureşului]. Anuarul Institutului de Studii Clasice 1, 89-101.

Kovács, I. (1944). A marosdécsei rézkori temető [The Copper Age cemetery in Marosdécse]. Közlemények Kolozsvár 4 (1-2), 3-21.

Kozintsev, A. (2019). Proto-Indo-Europeans: The prologue. The Journal of Indo-European Studies 47 (3-4), 293-380.

Kristiansen, K., Allentoft, M., Rei, K., Iversen, R., Johannsen, N., et al. (2017). Re-theorising mobility and the formation of culture and language among the Corded Ware Culture in Europe. Antiquity 91 (356), 334-347. https://doi.org/10.15184/aqy.2017.17

Kulcsár, G. (2013). Glimpses of the Third Millennium BC in the Carpathian Basin. In A. Anders \& G. Kulcsár (eds.), Moments in Time. Papers Presented to Pál Raczky on His 60th Birthday (pp. 643-659). Budapest: Ösrégészeti Társaság, ELTE - L’Harmattan.

Kulcsár, G. \& Szeverényi, V. (2013). Transition to the Bronze Age: Issues of Continuity and Discontinuity in the First Half of the Third Millennium BC in the Carpathian Basin. In V. Heyd, G. Kulcsár \& V. Szeverényi (eds.), Transitions to the Bronze Age. Interregional Interaction and Socio-Cultural Change in the Third Millennium BC Carpathian Basin and Neighbouring Regions (pp. 67-92). Budapest: Archaeolingua.

Kustár, R., Majkut, P., Csökmei, B. \& Sümegi, P. (2014). Az Oltó-halom (Dunatetétlen) geomorfológiai és régészeti geológiai vizsgálatának eredményei [Results of the geomorphological and archaeo-geological studies of the Oltó Hill (Dunatetétlen)]. In P. Sümegi (ed.), Környezetföldtani és környezettörténeti kutatások a dunai Alföldön (pp. 113-120). Szeged: SZTE-TTIK Földrajzi és Földtani Tanszékcsoport.

Laziridis, I. (2018). The evolutionary history of human populations in Europe. Current Opinion in Genetics \& Development 53, 21-27. https://doi.org/10.1016/j.gde.2018.06.007

Lehoczky, T. (1894a). A királyhelmeczi sírhalmokról [About the burial mounds in Királyhelmecz]. Archaeologiai Értesitö 14, 250-252. 
János Dani $\bullet$ Kurgans and their Builders. The Great Hungarian Plain at the dawn of the Bronze Age

Lehoczky, T. (1894b). A királyhelmeczi sírhalmok [The burial mounds in Királyhelmecz]. Archaeologiai Értesitö 14, 311-315.

Marcsik, A. (1971). Data of the Copper Age anthropological find of Bárdos-farmstead at CsongrádKettőshalom. Móra Ferenc Múzeum Évkönyve 1971 (2), 19-27.

Marcsik, A. (1979). The anthropological finds of the Pit-Grave kurgans in Hungary. In I. Ecsedy (ed.), The People of the Pit-Grave Kurgans in Eastern Hungary (pp. 87-98). Budapest: Akadémiai Kiadó.

Manzura, I. (Манзура, И.) (2000). Vladejushhie skipetrami (Владеющие скипетрами) [Тhose who have sceptres]. Stratum plus 2, 237-295.

Medović, P. (1987). Resultate der Untersuchungen auf drei Grabhügeln in der Gemarkung des Dorfes Perlez im mittleren Banat. In D. Srejović \& N. Tasić (Hrsg.), Hügelbestattung in der Karpaten-DonauBalkan-Zone während der äneolithischen Periode. Internationales Symposium Donji Milanovac 1985 (pp. 77-82). Beograd: Balkanološki Institut SANU.

Milesz, B. (1899). A tiszafüredi múzeum köréböl [From among the finds of the Riszafüred Museum]. Archaeologiai Értesitö 19, 79-84.

Milleker, B. (1901). Régészeti ásatások Ulmán [Archaeological excavations at Ulma]. Történelmi és régészeti értesitö. A délmagyarországi Történelmi és Régészeti Muzeumtársulat Közlönye 17 (3-4), 19-22.

Miloglav, I. (2018). Vučedolska kultúra (The Vučedol culture). In J. Balen, I. Miloglav \& D. Rajković (eds.), Povratak u prošlost. Bakreno doba u sjevernoj Hrvatskoj (Back to the Past. Copper Age in Northern Croatia) (pp. 113-145). Zagreb: FF Open Press. https://doi.org/10.17234/9789531758185-07

MRT 8 = Jankovich B., D., Makkay, J. \& Szőke, B. M. (1989). Békés megye régészeti topográfiája. A szarvasi járás. IV/2 [The archaeological topography of Hungary. The Szarvas region]. Magyarország régészeti topográfiája 8. (Archaeological sites of Hungary 8). Budapest: Akadémiai Kiadó.

Nikolaeva, A. N. (Н. А. Николаева) (2012). K voprosu o hronologii kamennyh skipetrov jepohi jeneolita/ bronzovogo veka (К вопросу о хронологии каменных скипетров эпохи энеолита/бронзового века) [The chronology of horsehead-shaped sceptres made of stone in the Eneolithic and Bronze Age.]. In V. A. Aljokshin et al. (eds.), Cultures of the Steppe Zone of Eurasia and Their Interaction with Ancient Civilizations. Materials of the International conference dedicated to the 110th birth anniversary of the outstanding Russian archaeologist Mikhail Petrovich Gryaznov. Vol. 2. (pp. 80-86). St. Petersburg: Russian Academy of Sciences, Institute for the History of Material Culture.

Olalde, I., Brace, S., Allentoft, M. E., Armit, I., Reich, D., et al. (2018). The Beaker phenomenon and the genomic transformation of northwest Europe. Nature 555 (7695), 190-196. http://doi.org/10.1038/ nature 25738

Patay, R. (2020, in press). Adatok a késő rézkor és a kora bronzkor átmeneti időszakához: Cegléd 4/4. Lelöhely [New data on the transition between the Late Copper and the Early Bronze Age: The site Cegléd 4/4]. In S. Gulyás, D. Molnár, K. Náfrádi \& T. Töröcsik (eds.), Negyedidöszaki környezettörténet. Tanulmányok Prof. Sümegi Pál 60. születésnapjára. Szeged.

Potushniak, F. М. (Потушняк, Ф. М.) (1958). Arheologichni znahidki bronzovogo ta zaliznogo viku na 
János Dani $\bullet$ Kurgans and their Builders. The Great Hungarian Plain at the dawn of the Bronze Age

Zakarpatti (Археологічні знахідки бронзового та залізного віку на Закарпатті) [Bronze and Iron Age archaeological finds from Zakarpattia Oblast]. Uzhhorod.

Rascovan, N., Sjögren, K. G., Kristiansen, K., Nielsen, R., Willerslev, E., et al. (2019). Emergence and spread of basal lineages of Yersinia pestis during the Neolithic decline. Cell 176 (1-2), 295-305. http://doi. org/10.1016/j.cell.2018.11.005

Rasmussen, S., Allentoft, M. E., Nielsen, K., Nielsen, R., Kristiansen, K., et al. (2015). Early divergent strains of Yersinia pestis in Eurasia 5000 years ago. Cell 163 (3), 571-582. http://doi.org/10.1016/j. cell.2015.10.009

Rassamakin, Y. Y. (2012). Eneolithic Burial Mounds in the Black Sea Steppe: From the First Burial Symbols to Monumental Ritual Architecture. In E. Borgna \& S. Müller Cerka (eds.), Ancestral Landscapes. Burial Mounds in the Copper and Bronze Ages (Central and Eastern Europe - Balkans - Adriatic - Aegean, 4th-2nd millennium B. C.). Proceedings of the International Conference held in Udine, May 15th-18th 2008 (pp. 293-306). Travaux de la Maison de l'Orient et de la Méditerranée. Série recherches archéologiques 58. Lyon: Maison de l'Orient et de la Méditerranée Jean Pouilloux.

Rassamakin, Y. Y. (2013). From the Late Eneolithic Period to the Early Bronze Age in the Black Sea Steppe: What is the Pit Grave Culture (Late Fourth to Mid-Third Millennium BC)? In V. Heyd, G. Kulcsár \& V. Szeverényi (eds.), Transitions to the Bronze Age. Interregional Interaction and Socio-Cultural Change in the Third Millennium BC Carpathian Basin and Neighbouring Regions (pp. 113-138). Budapest: Archaeolingua.

Reményi, L. (2018). A bronzkori településtörténeti változások értelmezése az új kronológiai adatok alapján (Die Interpretation von bronzezeitlichen siedlungsgeschichtlichen Änderungen mit Hilfe der neuen chronologischen Angaben). In A. Korom (ed.), Relationes rerum. Régészeti tanulmányok Nagy Margit tiszteletére (Relationes rerum. Archäologische Studien zu Ehren von Margit Nagy) (pp. 47-56). Studia ad Archaeologiam Pazmaniensia 10. Budapest: PPKE - BTM - Archaeolingua.

Roman, P. I. (1976). Cultura Coţofeni [The Coţofeni culture. Biblioteca de Arheologie 35. Bucuresti: Editura Academiei Republicii Socialiste Romania.

Roman, P. (1980). Der „Kostolac-Kultur” - Begriff nach 35 Jahren. Prähistorische Zeitschrift 55 (2), 220-227. https://doi.org/10.1515/prhz.1980.55.2.220

Roman, P., Dodd-Opriţescu, A. \& János, P. (1992). Beiträge zur Problematik der Schnurverzierten Keramik Südosteuropas. Mainz: Zabern.

Sachsse, C. (2012). Burial Mounds in the Baden Culture: Aspects of Local Developments and Outer Impacts. In E. Borgna \& S. Müller Celka (eds.), Ancestral Landscape. Burial mounds in the Copper and Bronze Ages (Central and Eastern Europe - Balkans - Adriatic - Aegean, 4th-2nd millennium B. C.) Proceedings of the International Conference held in Udine, May 15th-18th 2008 (pp. 127-134). Travaux de la Maison de l'Orient et de la Méditerranée. Série recherches archéologiques 58. Lyon: Maison de l'Orient et de la Méditerranée Jean Pouilloux.

Schuster, C., Mirea, P. \& Haită, C. (2015). Zu einem besonderen kreuzförmigen steinernen Zepterkeulentyp: Roşiorii de Ved - Despre un tip aparte de capăt de sceptru cruciform din piatră: Roşiorii de Vede. In C. Schuster, C. Tulugea \& C. Terteci (eds.), Buridava XII/1 - Symposia Thracologica X. Volum dedicat 
János Dani $\bullet$ Kurgans and their Builders. The Great Hungarian Plain at the dawn of the Bronze Age

profesorului Petre I. Roman la cea de-a 80-a aniversare - Volume Dedicated to Professor Petre I. Roman on his 80th Anniversary (pp. 144-155). Râmnicu Vâlcea.

Solymossy, E. (1895). Az oklándi kunhalmokról (Udvarhely m.) [About the Cumanian mounds in Oklánd (Udvarhely County)]. Archaeologiai Értesítö 15, 417-419.

Srejović, D. (1976). Humke stepskih odlika na teritoriji Srbije (Mounds of kurgan character is Serbia). Godišnjak Centar za Balkanološka Ispitivanja 13, 117-130.

Sz. Máthé, M. (1975). Rómer Flóris bihari munkássága (A bihari útinapló) [The work of Flóris Rómer in Bihar (His Bihar diary)]. A Debreceni Déri Múzeum Évkönyve 1974, 283-346.

Szabó, J. (1859). A békés-csanádi halmok földtani tekintetben [The mounds in Békés-Csanád from a geological perspective]. Budapesti Szemle 6, 175-187.

Szabó, G. (2017). Problems with the periodization of the Early Bronze Age in the Carpathian Basin in light of the older and recent AMS radiocarbon data (A Kárpát-medencei kora bronzkor periodizációjának nehézségei a régi és az újabb AMS radiokarbon adatok tükrében). Archeometriai Mühely 14 (2), 99-116.

Szász, H. (2017). Kora bronzkori halomsíros temetők Délkelet-Erdélyben [Early Bronze Age tumulus cemeteries in Southeastern Transylvania]. Paper presented at the 20th Transylvanian Students' Scientific Conference, Cluj Napoca, 18-21 May 2017. https://www2.sci.u-szeged.hu/ABS/Acta\%20HP/44-75.pdf Accessed: 3 June 2020.

Tariczky, E. (1906). A tiszavidéki hun földpyramis-halmok ismertetése [About the Hunnic earthen pyramids in the Tisa region]. Eger.

Tasić, N. (1995). Eneolithic Cultures of Central and West Balkans. Belgrade: Draganić.

Tóth, A. (2009). Rekviem a kunhalmokért (Requiem für die Kumanenhügel). Tisicum 19, 481-491.

Valtueña, A. A., Mittnik, A., Key, F. M., Haak, W., Stockhammer, P. W., et al. (2017). The Stone Age plague and its persistence in Eurasia. Current Biology 27 (23),3683-3691.http://doi.org/10.1016/j.cub.2017.10.025

Zoltai, L. (1911). Jelentések halmok megásatásáról [Reports on the excavations of mounds]. In Jelentés Debreczen sz. kir. város múzeuma 1910. évi müködéséröl és állapotáról (pp. 40-46). Debrecen.

Zoltai, L. (1938). Debreceni halmok, hegyek, egyéb mesterséges és természetes emelkedések ú.m.: laponyagok, telkek, ülések, dombok, gerendek és hátak a város határában, valamint külsö birtokain [Mounds, hills and other natural and artificial elevations, that is, dunes, ridges, slopes in the outskirts of the town of Debrecen and in its surroundings]. Debrecen: Városi Nyomda. 